\title{
The mineralogy, geochemistry and genesis of the alluvial platinum-group minerals of the Freetown Layered Complex, Sierra Leone
}

\author{
John F. W. Bowles ${ }^{1, *}$, Saioa Suárez ${ }^{2,3}$, Hazel M. Prichard ${ }^{2, \dagger}$ and Peter C. Fisher ${ }^{2}$ \\ School of Earth and Environmental Sciences, University of Manchester, Manchester M13 9PL, UK \\ School of Earth and Ocean Sciences, Main College. Park Place, Cardiff University, Cardiff CF10 3AT, Wales \\ Department of Mineralogy and Petrology, UPV/EHU, 48940 Leioa and Ikerbasque, 48011 Bilbao, Spain
}

[Received 8 January 2017; Accepted 13 May 2017; Associate Editor: Nigel Cook]

\section{ABSTRACT}

Heavy mineral concentrates from rivers and river terraces near York, Freetown Peninsula, Sierra Leone have been examined for their platinum-group mineral (PGM) content. The alluvial PGM are 0.1 to $1.5 \mathrm{~mm}$ in size and include $\mathrm{Cu}$-bearing isoferroplatinum $\left(\mathrm{Pt}_{3} \mathrm{Fe}\right)$ and disordered $\mathrm{Pt}_{3-x} \mathrm{Fe}(x \leq 0.38)$, tulameenite $\left(\mathrm{Pt}_{2} \mathrm{FeCu}\right)$, hongshiite $(\mathrm{PtCu})$, cooperite-vysotskite $(\mathrm{PtS}-\mathrm{PdS})$, laurite $\left(\mathrm{RuS}_{2}\right)$, erlichmanite $\left(\mathrm{OsS}_{2}\right)$, Os-Ir alloy, Os- $\mathrm{Ru}$ alloy and native copper.

Are the alluvial nuggets primary or a neoformation? Comparison of the PGM mineralogy of fresh rocks, weathered rocks and the saprolite, with the alluvial suite shows strongly contrasting features highlighted by the mineral assemblage. Cooperite in the fresh rocks is rare in the alluvium whilst Pt-Fe alloys become more abundant. Oxidized PGM are a feature only of the weathering process and disordering of the Pt-Fe alloys develops during weathering. Palladium is much less abundant in the alluvial suite than in the primary minerals whereas $\mathrm{Cu}$, present as $\mathrm{Cu}$-sulfides in the fresh rocks, occurs in the alluvium as a minor component of the Pt-Fe alloys and as hongshiite alteration to the Pt-Fe alloys. The size difference is striking; the primary mineralogy is micrometre-sized whereas the alluvial PGM are three orders of magnitude larger. Delicate PGM with alteration textures are seen only in the weathered rocks whilst delicate dendritic PGM are reported only from the alluvial suite. An organic coating to the alluvial PGM may be indicative of an organic or bacterial involvement. Some alluvial PGM occur in a drainage basin devoid of outcrops of PGE-bearing horizons.

Together these contrasting features of the primary and placer PGM support the proposal that the Freetown nuggets developed as a result of breakdown of the primary PGM during weathering, movement of the PGE in solution, and growth of new PGM in placers with a different mineral assemblage, mineralogy and mineral chemistry.

KEYWoRDs: platinum-group minerals, Freetown Intrusion, Sierra Leone, alluvial, nuggets.

\section{Introduction}

*E-mail: john.bowles@manchester.ac.uk

${ }^{\dagger}$ Died 1 January 2017

https://doi.org/10.1180/minmag.2017.081.032
Alluvial platinum-group minerals (PGM) in the western hills of the Freetown Peninsula, Sierra Leone, West Africa were first found in 1926 (Junner, 1929, 1930; Pollet, 1931, 1951).

This paper is part of a special issue entitled 'Critical-metal mineralogy and ore genesis'. The Applied Mineralogy Group of the Mineralogical Society and the IMA Commission on Ore Mineralogy have contributed to the costs of Open Access publication for this paper.

(C) The Mineralogical Society 2018. This is an Open Access article, distributed under the terms of the Creative Commons Attribution licence (http://creativecommons.org/licenses/by/4.0/), which permits unrestricted re-use, distribution, and reproduction in any medium, provided the original work is properly cited. 


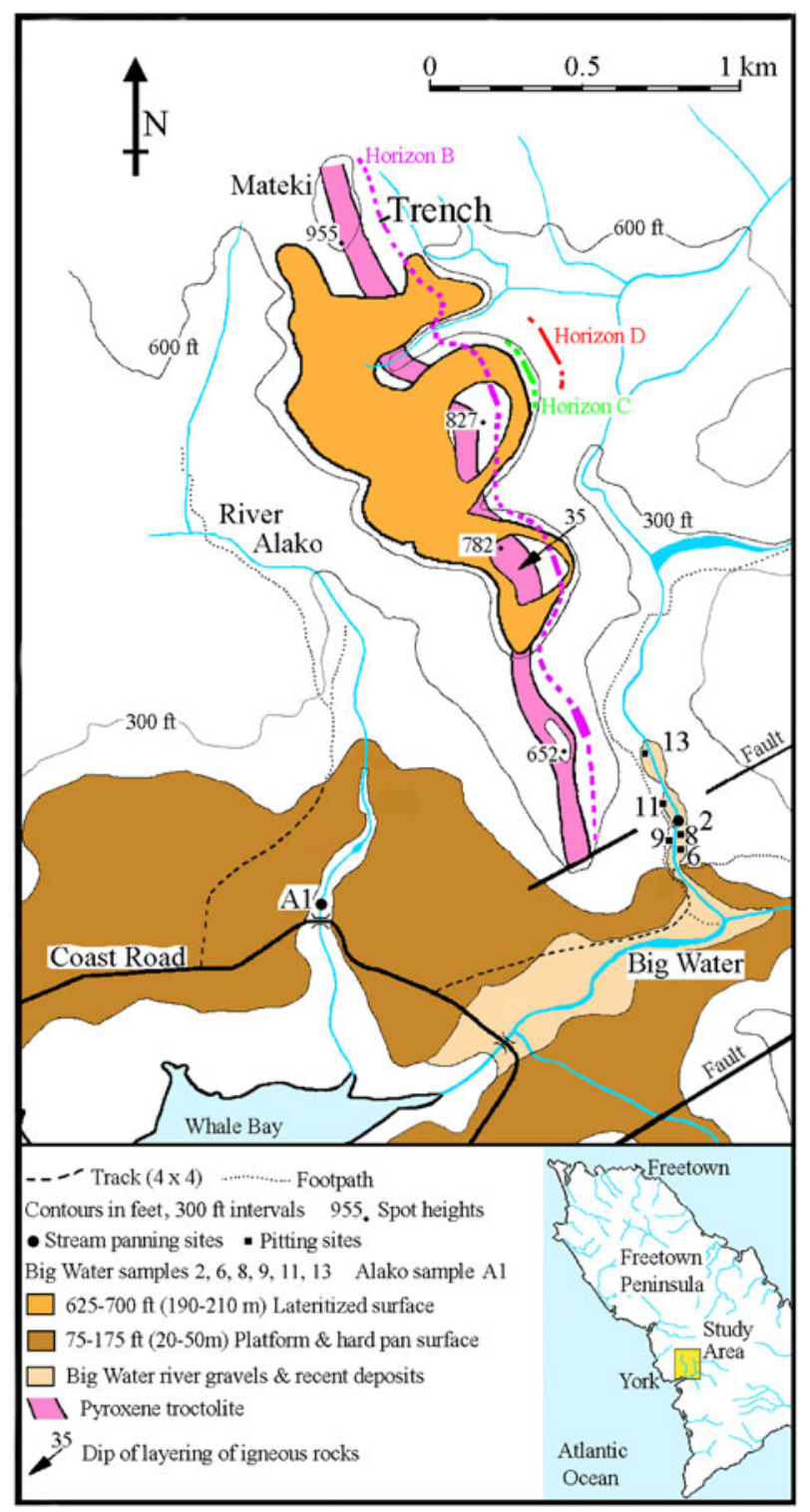

FIG. 1. Map of the York area, Freetown Peninsula, Sierra Leone showing the known occurrences of the primary PGEbearing layers Horizon B, Horizon C and Horizon D, the main lateritized surfaces, and the sampling sites in the Alako and Big Water rivers, either side of Mateki Ridge.

Artisanal mining recovered the PGM from small rivers known locally as Big Water, and the Alako in the York area (Fig. 1) and, subsequently, from Guma Water and the Babadori further to the north ( Pollet, 1931, 1951; Barber, 1962, Forde, 2011).

The PGM from the Freetown Complex have been examined in detail from the Babadori (Pollet, 1951) and Guma Water areas (Pollet, 1931; Bowles, 1981, 1986, 1988, 2000a; Bowles et al., 1983; Hattori et al., 1991, 1996; Cabri et al., 1996). The alluvial PGM consist mainly of Pt-Fe alloys. Euhedral crystals of Os-Ir alloys and laurite-erlichmanite $\left(\mathrm{RuS}_{2}-\mathrm{OsS}_{2}\right)$ can be set in the Pt-Fe alloys or occur independently. Minor proportions of tulameenite $\left(\mathrm{Pt}_{2} \mathrm{CuFe}\right)$ are also present. Sulfides of platinum- 
group elements (PGE) and tellurides as well as $\mathrm{Cu}-$ sulfides have been reported as inclusions within the Pt-Fe nuggets. The nuggets have a coarse grain size, usually in the range 0.5 to $2 \mathrm{~mm}$ but considerably larger nuggets $(1-2 \mathrm{~cm})$ have been reported, including dendritic crystalline growths (Pollet, 1951).

The processes that result in the presence of the PGM in placer deposits have been the subject of debate. Two contrasting models have been proposed for the formation of PGM and the most likely situation is that both processes contribute, depending upon local conditions. The first process involves primary formation of large PGE grains within an intrusion, followed by weathering where PGM are liberated and transported mechanically with no alteration apart from surface abrasion of the nuggets (Cabri et al., 1996; Weiser, 2002 and references therein). This process undoubtedly occurs where large PGM are present in the host rocks and the weathering is purely mechanical as in temperate, cold and polar climates. The major problems with this proposal are the contrast in the primary and the alluvial mineral assemblages, mineral chemistry as well as the three orders of magnitude difference in the size of the PGM placer nuggets compared with those found in the igneous rock. Several authors (e.g. Oberthür et al., 2003) have been able to find rare large PGM within the host rocks and have shown that the size difference might just be a question of appropriate sampling. To date no indication of any occurrence of large PGM has been encountered in the Freetown rocks despite lithogeochemical and geomagnetic surveys of the area. Micrometre-sized PGM have been located in the rocks (Bowles, 2000b; Bowles et al., 2013, 2017) but it is the differences between the mineral assemblages in the primary and placer occurrences which are most significant (Bowles, 1981; Bowles et al., 2000a, 2013; Oberthür et al., 2013).

The second model involves solution of PGE during weathering, possibly aided by biochemical leaching and high Eh and low $\mathrm{pH}$ conditions. This is followed by transport of the PGE in solution leading to supergene growth of nuggets within lateritic soils where conditions such as lower Eh and neutral $\mathrm{pH}$ favour deposition (Fuchs and Rose, 1974; Bowles, 1986, 1988; Bowles et al., 1994a, 2000; Talovina and Lazarenkov, 2001; Aiglsperger et al., 2015, 2016). The problem with this model is that the mechanisms of this process are largely unknown and the evidence circumstantial. There is clear evidence of alteration and weathering of the primary PGM leading to transport of PGE in solution (Bowles et al., 2017). The Fe content of the altered product remains within the range encountered for the Pt-Fe alloys. The change in composition associated with the alteration of $\mathrm{Pt}-\mathrm{Fe}$ alloy is principally a loss of $\mathrm{Pt}$ and a gain of $\mathrm{O}$ or $\mathrm{OH}$. Bowles (1986) argued that the Eh and $\mathrm{pH}$ of iron-rich, lateritized soils are sufficiently extreme to allow the formation of Pt-oxide but Hattori et al. (2010) have found that alteration in New Caledonia has produced a very fine-grained mixture of relict Pt-Fe alloy and Fe-oxides or hydroxides. We have not yet examined the Freetown material in this detail so this paper uses 'oxidized PGM' to describe the alteration product. How can neoform growth lead to the formation of large nuggets? The contribution by Reith et al. (2016) offers a mechanism for bacterially-aided mineral growth. The nuggets are normally single crystals with no sign in polished section of the remains of grain boundaries that could suggest mechanical or chemical 'agglutination'. The explanation for nugget formation must include early nuclei to be a preferred site for continued growth.

Occurrences of eluvial and alluvial PGM that exhibit a contrasting mineralogy to their source rocks have been reported especially in areas of long duration intense weathering such as tropical weathering of ancient cratons. Examples include placer deposits derived from ophiolitic chromitites in Borneo (Burgath, 1988); serpentinite lateritic coatings in Cameroon (Ndjigui and Bilong, 2010); lateritic soils covering the deeply weathered Yubdo ultramafic intrusion, Ethiopia (Belete et al., 2000, 2002), the Uktus Complex in Central Urals, Russia (Talovina and Lazarenkov, 2001; Zaccarini et al., 2013), supergene leaching leading to neoformation in Minas Gerais, Brazil (Cabral et al., 2007, 2008) and PGM neoformation in Ni-laterites, Dominican Republic (Aiglsperger et al., 2015, 2016, 2017). Evidence from the rivers draining The Great Dyke in Zimbabwe (Oberthür et al., 2013) provides a view of the process from start to finish. Here PGEbismuthotellurides and sulfarsenides found in the pristine sulfide-bearing zone and oxidized PGM in the oxide zone (Oberthür et al., 2003) are absent from the alluvium. Pt-Fe alloys occur instead, the majority of which are considered to be neoformations.

It is relevant that the Freetown intrusion has undergone a very long period of weathering. Wavecut platforms indicate erosion and weathering have been active since the Eocene (Gregory, 1962). In addition, the peninsula is exposed to very heavy rainfall, which is currently $3000-5000 \mathrm{~mm} /$ year 
(Hughes and Hughes, 1992). The source of the Freetown placer PGM was obscure until recently, so comparison of the source, the eluvial deposits and the placers was not possible. Bowles (2000b) and Bowles et al. (2013) defined four stratiform layers of magnetite-bearing gabbros with PGE mineralization (up to $0.69 \mathrm{~g} / \mathrm{t} \mathrm{Pt}$ ) and $\mathrm{Cu}$-rich sulfides describing a primary source of the Freetown PGM and identifying primary PGM for the first time. The host rocks are fresh with coarsegrained olivine, plagioclase, clinopyroxene, orthopyroxene and later, interstitial, amphibole (Bowles et al. 2013). There has been re-equilibration of the Fe-Ti-oxides during cooling but no indication of significant metamorphism or serpentinization. The PGM occur in the interstices between the main silicate minerals and within the late amphibole. The PGM in the host rocks are considered here to be 'primary PGM', the PGM that have been altered by weathering are described as 'weathered PGM' and the different alluvial suite are called 'neoform PGM'.

Bowles et al. (2017) investigated the sequence of mineralogical changes undergone by the primary PGE mineralization during in situ weathering. The present contribution uses results from a systematic survey of the alluvial PGM from the river terraces and the beds of the Alako and the Big Water (Fig. 1) that drain PGE-bearing horizons to compare the PGM in the primary and weathered rocks with those in the alluvial assemblage to assess the origin of the secondary PGM.

\section{Platinum from the Freetown Peninsula}

In 1926 Pt-bearing grains were found in the westward draining streams of the complex and, by 1949, 5242 oz of platinum concentrate had been recovered. Analysis of the concentrate showed Pt 87, Pd 2, Os + Ir 1.3 and Fe 9.9 wt.\% (Pollett, 1931). The extraction used artisanal methods with sluice boxes and local labour panning by hand. It is worth quoting the description of the alluvial occurrences from Pollett (1931). "Platinum in the native state occurs in the gravels of streams draining the hills forming the peninsula of Sierra Leone. To a limited extent it has also been found in beach gravels in certain coast localities. The most promising deposits are in the vicinity of York, more specifically in the streams flowing into Whale River on its northern banks. Here the metal occurs as small nuggets, pitted and water worn grains, delicate dendritic crystalline growths and dust. Occasionally cubic crystals are found. Many of the small nuggets and water-worn grains have a peculiar brass colour. The largest nugget yet recovered weighed $12 \frac{1}{2} \mathrm{dwt}$., and numerous nuggets ranging between 5 and $10^{1} / 2$ dwt. have been found." [ $1 \mathrm{dwt}$ or one pennyweight is $20 \mathrm{~g}$, so the weights mentioned range from 10 to $250 \mathrm{~g}$ ]. "These larger nuggets are invariably well water worn. An interesting feature is the presence of practically non water worn, delicate dendritic crystalline growths of platinum in gravels that also contain well-rounded grains of the metal. This dendritic non water worn form, however, is rarely seen in fragments larger than $1 / 2 \mathrm{dwt}$. Another noticeable feature is the small percentage of platinum dust."

The platinum described as being in the native state is now known to be platinum-iron alloy, occurring as $\mathrm{PtFe}$ and $\mathrm{Pt}_{3} \mathrm{Fe}$ (Bowles, 1981). The density of isoferroplatinum $\left(\mathrm{Pt}_{3} \mathrm{Fe}\right)$ is $18.2 \mathrm{~g} / \mathrm{cc}$ and that of tetraferroplatinum (PtFe) is $15.2 \mathrm{~g} / \mathrm{cc}$. For the purposes of an illustrative calculation an intermediate value of $16 \mathrm{~g} / \mathrm{cc}$ can be chosen so the 'largest nugget yet recovered' $\left(12^{1} / 2\right.$ dwt.) could be represented by a cube with an edge of $2.5 \mathrm{~cm}$ ! The numerous nuggets of 5 to $10^{1} / 2$ dwt. would have had a volume corresponding to cubes with edges of 1.8 to $2.4 \mathrm{~cm}$ and the dendritic growths reached a volume equivalent to a cube with an edge of $0.85 \mathrm{~cm}$.

Experiments with nuggets from the present study have shown that the 'brass colour' of the PGM is a coating of Fe- and Al-oxides and organic matter that can be removed by washing in warm $6 \mathrm{M} \mathrm{HCl}$ for 1 to 2 days and then reacting with $30 \% \mathrm{H}_{2} \mathrm{O}_{2}$ for about one month. The coating hides the otherwise silvery colour of the nuggets making them difficult to locate in the sediments. This coating appears comparable with the biofilms identified by Reith et al. (2016).

The description of the morphology of the PGM by Pollett (1931) is comparable with the PGM from Guma Water, Freetown described by Bowles (1981). The 'small percentage of platinum dust' may be a result of panning and hand picking of the grains in the presence of a large amount of coarse black sand so that fine-grained PGM would not have been recovered.

Pollett (1951) suggested that artisanal mining had ceased because of a low platinum price and it was unclear if economic PGM concentrations remained. Therefore, exploratory surveys of the alluvium were undertaken by panning in the streams and by pitting of the river terraces to assess the present situation, and also to aid the search for the hard-rock source. 


\section{Methods}

\section{Alluvial sampling and analysis}

The alluvial samples consist of black sand concentrates collected from stream beds and pits in the river terraces (Tables 1 and 2, Fig. 1). Gravel from the beds of the Alako (sample A1) and Big Water (sample BW2) was panned by a team of local workers. At each site a volume of gravel corresponding to 30 'standard head pans' was reduced to black sand. The head pan is a shallow wooden dish $\sim 70 \mathrm{~cm}$ in diameter that the local workers use for panning (and for carrying goods on the head hence the name). The volume of a head pan was measured by filling it with water and weighing. The result indicated a volume of 11.68 litres although that represents the pan filled to the brim whereas a pan filled with gravel was often piled above the brim. For the purposes of estimation of a grade in the source material, a pan volume of 12 litres has been used. During panning of the streams rocks and boulders were avoided so the grade calculated in this way is an overestimate of a grade that would be achieved by mechanical extraction. The black sand from the rivers was split using a riffle splitter and a split assayed for $\mathrm{Pt}, \mathrm{Pd}$ and $\mathrm{Au}$ by Lakefield Research in Canada.

The river terraces either side of Big Water were examined by pitting. Square pits, $1.5 \mathrm{~m}$ on each side, were dug and all of the material panned (Pits BW6 - BW13, only pits reporting significant Pt values are discussed here). The depth of the pits was variable and constrained by reaching bedrock or rapid ingress of water through gravel below the water table. A '4 inch' (100 mm diameter input) pump only allowed limited progress below the water table and an auger was used for deeper samples. Each interval of $0.5 \mathrm{~m}$ in depth in the pit was treated as a separate sample and panned to black sand. Each sample was dried on site and subsequently subsampled using a riffle splitter before assay only for Pt by Lakefield Research of Canada. High Pt assay results were checked by repeat assays.

\section{Recovery and study of the PGM}

The black sand concentrates $(60-500 \mathrm{~g}$ of each sample) were panned again in the laboratory to recover the densest fraction and the PGM nuggets found during the process were hand picked. The remaining lightest fraction was processed with a Frantz LB-1 Magnetic Barrier Separator fitted with a Low Field Control Unit, which allowed a satisfactory separation of the most ferromagnetic and diamagnetic fractions. The majority of the alluvial nuggets were hand picked from the dense and the less magnetic fractions using a stereoscopic microscope. All the PGM recovered from the samples were mounted separately on stubs for examination of their morphology and, subsequently, in polished blocks for analysis using a Zeiss SMT S360 analytical scanning electron microscope (SEM) with an Inca EDX system at Cardiff University under the same analytical conditions described by Bowles et al. (2017). The remainder of the densest fraction of each sample was also examined by SEM to search for grains overlooked during hand picking.

\section{Assay results and their relationship to drainage}

Assays of the samples described here are shown in Table 1 (panning in the rivers) and Table 2 (pitting the river terraces). Repeated assay values show a significant variation due to the 'nugget effect'. The assay values are reported as a proportion of the black sand and they have been converted to 'bank grade' to estimate the proportion of $\mathrm{Pt}$ in the sediment. The results all relate to small volumes of gravel and do not suggest an economic potential.

Pitting in the level river terrace of the east bank of the Big Water (pits BW6 and BW8) revealed gravel and lateritized soils to a depth of $\sim 2 \mathrm{~m}$ overlying weathered bedrock. On the west bank soil overlies gravel in pit BW13. Soil and weathered bedrock are found between the patches of gravel and the boulders in pit BW11. These pits are at the foot of a steep hillside below the ridge on which the PGM-bearing horizons have been reported (Bowles, 2000b; Bowles et al., 2013) and there has clearly been some slumping.

Platinum concentrations appear in the upper $0.5 \mathrm{~m}$ of sediment (up to $135 \mathrm{~g} / \mathrm{t} \mathrm{Pt}$ in black sand), at the bottom of some pits in weathered bedrock (up to 58.3 $\mathrm{g} / \mathrm{t}$ Pt in black sand) and in intermediate horizons (up to $39.5 \mathrm{~g} / \mathrm{t}$ in black sand) with no consistent pattern (Table 2). As a Pt concentration in the sediment, the highest values (up to $117.6 \mathrm{mg} \mathrm{Pt} / \mathrm{m}^{3}$ ) occur close to bedrock but the near surface sediment can contain up to $48 \mathrm{mg} \mathrm{Pt} / \mathrm{m}^{3}$. The Pt assays from the gravel in the Alako and the Big Water are similar and in the same range as the Big Water terraces (Table 1). The $\mathrm{Pd}$ and $\mathrm{Au}$ assay results are low resulting in very high $\mathrm{Pt} / \mathrm{Pd}$ and $\mathrm{Pt} / \mathrm{Au}$ ratios. 
TABLE 1. Panning of river gravels using a 'headpan'.

\begin{tabular}{|c|c|c|c|c|c|c|c|}
\hline \multirow[b]{2}{*}{ Sample number } & \multirow{2}{*}{$\begin{array}{c}\text { Weight of } \\
\text { black sand (kg) }\end{array}$} & \multicolumn{5}{|c|}{ Assay results } & \multirow{2}{*}{$\begin{array}{c}\text { Bank grade } \\
\mathrm{mg}(\mathrm{Pt}+\mathrm{Pd}+\mathrm{Au}) \\
\text { per } \mathrm{m}^{3}\end{array}$} \\
\hline & & $\operatorname{Pt}(\mathrm{g} / \mathrm{t})$ & $\operatorname{Pd}(g / t)$ & $\mathrm{Au}(\mathrm{g} / \mathrm{t})$ & $\mathrm{Pt} / \mathrm{Pd}$ & $\mathrm{Pt} / \mathrm{Au}$ & \\
\hline Alako & & & & & & & \\
\hline A 1 & 2.20 & 29.50 & n.d. & 0.08 & $>1475$ & 369 & 130 \\
\hline $\begin{array}{l}\text { Big Water } \\
\text { BW } 2\end{array}$ & 12.20 & 14.90 & 0.18 & 0.03 & 83 & 496 & 370 \\
\hline
\end{tabular}

n.d. - less than detection limit $(0.02 \mathrm{~g} / \mathrm{t})$.

The bank grade is an estimate of the in situ grade calculated using a 'headpan' volume of 12 litres and a factor of 1.38 to allow for the difference between the loose gravel in the pan and the undisturbed gravel. It is an overestimate as boulders were avoided when the gravel was collected.

TABLE 2. Results from pitting in the Big Water river terraces.

\begin{tabular}{|c|c|c|c|c|c|c|c|c|}
\hline \multirow{2}{*}{$\begin{array}{l}\text { Sample } \\
\text { number }\end{array}$} & \multirow{2}{*}{$\begin{array}{l}\text { Depth } \\
\text { (m) }\end{array}$} & \multirow[b]{2}{*}{ Lithology } & \multirow{2}{*}{$\begin{array}{l}\text { Weight of } \\
\text { black sand } \\
(\mathrm{kg})\end{array}$} & \multirow[b]{2}{*}{$\mathrm{Pt}(\mathrm{g} / \mathrm{t})$} & \multicolumn{3}{|c|}{ Repeat assays } & \multirow{2}{*}{$\begin{array}{l}\text { Bank grade } \\
\left(\mathrm{mg} \mathrm{Pt} / \mathrm{m}^{3}\right)\end{array}$} \\
\hline & & & & & $\operatorname{Pt}(g / t)$ & $\mathrm{Pt}(\mathrm{g} / \mathrm{t})$ & $\operatorname{Pt}(\mathrm{g} / \mathrm{t})$ & \\
\hline \multicolumn{9}{|c|}{ Pits on the east bank } \\
\hline BW $6 \mathrm{~A}$ & $0-0.5$ & $10 \mathrm{~cm}$ soil + fine gravel & 1.91 & 0.75 & & & & 1.3 \\
\hline BW 6B & $0.5-1.0$ & Fine gravel & 3.15 & 0.63 & & & & 1.8 \\
\hline $\mathrm{BW} 6 \mathrm{C}$ & $1.0-1.5$ & Gravel with boulders & 7.03 & n.d. & & & & 0 \\
\hline BW $6 \mathrm{D}$ & $1.5-2.0$ & Gravel with big boulders at base & 5.97 & 1.57 & & & & 8.3 \\
\hline BW $6 \mathrm{E}$ & $2.0-2.2$ & Orange-red weathered bedrock & 1.54 & 58.30 & 10.40 & & & 117.6 \\
\hline BW 8A & $0-0.5$ & Dark brown soil & 0.48 & 9.64 & 16.30 & 17.20 & 25.90 & 7.5 \\
\hline BW 8B & $0.5-1.0$ & Red to orange brown soil & 1.55 & 0.72 & & & & 1.0 \\
\hline $\mathrm{BW} 8 \mathrm{C}$ & $1.0-1.5$ & Red to orange brown soil & 2.24 & 0.35 & & & & 0.7 \\
\hline BW 8D & $1.5-2.0$ & $\begin{array}{l}\text { White clay \& gravel, boulders } \\
\text { in pit wall, } 20 \mathrm{~cm} \text { gravel at } \\
\text { base }\end{array}$ & 2.42 & 0.21 & & & & 0.5 \\
\hline BW 8E & $2.0-2.15$ & White clay & 0.37 & 2.86 & & & & 3.1 \\
\hline \multicolumn{9}{|c|}{ Pits on the west bank } \\
\hline BW 9A & $0-0.5$ & $10 \mathrm{~cm}$ soil + orange soil below & 0.59 & 51.20 & 103.0 & 76.9 & 135.0 & 48.0 \\
\hline BW 9B & $0.5-1.0$ & Kharki-brown soil & 0.43 & 0.51 & & & & 0.2 \\
\hline BW 9C & $1.0-1.5$ & $\begin{array}{l}\text { Auger sample below water } \\
\text { table }\end{array}$ & 0.30 & 0.11 & & & & 0.03 \\
\hline BW 11A & $0-0.5$ & Brown soil & 0.81 & 0.15 & & & & 0.1 \\
\hline BW 11B & $0.5-1.0$ & Orange soil with some boulders & 1.21 & 39.50 & 1.95 & & & 22.3 \\
\hline BW $11 \mathrm{C}$ & $1.0-1.5$ & Orange soil, many big boulders & 1.37 & 0.29 & & & & 0.4 \\
\hline BW 13A & $0-0.5$ & $\begin{array}{l}20 \mathrm{~cm} \text { soil gravel }+ \text { boulders } \\
\text { below }\end{array}$ & 3.82 & 2.67 & & & & 9.1 \\
\hline BW 13B & $0.5-1.0$ & Gravel + abundant boulders & 4.80 & 19.30 & & & & 82.3 \\
\hline
\end{tabular}

The samples studied are shown in bold type.

The Alako and the Big Water drain entirely different sequences of the layered rocks yet the alluvial PGM are similar. The Alako runs for $2 \mathrm{~km}$ along the west side of Mateki Ridge in a small, well defined watershed that does not include known PGM-bearing horizons. Drilling in this area (Barber, 1962) was not followed up. There is no evidence of river capture or change of course that 
TABLE 3. Alluvial PGM in the Big Water and Alako.

\begin{tabular}{|c|c|c|c|c|c|c|c|}
\hline \multirow[b]{3}{*}{ Sample } & \multicolumn{5}{|c|}{ Big Water } & \multirow{3}{*}{$\begin{array}{c}\begin{array}{c}\text { Alako } \\
\text { River }\end{array} \\
\\
\text { Alako1 } \\
\text { Panned }\end{array}$} & \multirow[b]{3}{*}{ Totals } \\
\hline & \multicolumn{2}{|c|}{ West bank terrace } & \multirow{2}{*}{$\begin{array}{c}\text { River } \\
\text { BW2C } \\
\text { Panned }\end{array}$} & \multicolumn{2}{|c|}{ East bank terrace } & & \\
\hline & $\begin{array}{c}\text { BW13B } \\
\text { Pit }\end{array}$ & $\begin{array}{l}\text { BW9A } \\
\text { Pit }\end{array}$ & & $\begin{array}{c}\text { BW8A } \\
\text { Pit }\end{array}$ & $\begin{array}{c}\text { BW6E } \\
\text { Pit }\end{array}$ & & \\
\hline \multicolumn{8}{|l|}{ Nuggets } \\
\hline Number & 1 & 5 & 13 & 1 & 12 & 4 & 36 \\
\hline Size $(\mu \mathrm{m})$ & $263 \times 318$ & $80-1540$ & $134-635$ & $249 \times 228$ & $119-822$ & $167-1030$ & \\
\hline Shape & & & & & & & $\%$ \\
\hline Euhedral & 1 & & 1 & & 1 & 1 & 11.1 \\
\hline Subrounded & & 1 & 2 & & 3 & 1 & 19.4 \\
\hline Rounded & & & 2 & & 2 & & 11.1 \\
\hline Elongate & & 2 & 3 & & 3 & 1 & 25.0 \\
\hline Irregular & & 2 & 5 & 1 & 3 & 1 & 33.3 \\
\hline Composition & & & & & & & $\%$ \\
\hline $\mathrm{Pt}_{3} \mathrm{Fe}$ & & 2 & 11 & & 5 & 3 & 58.3 \\
\hline $\mathrm{Pt}_{3-x} \mathrm{Fe}(x=0.16-0.38)$ & & 3 & 2 & & 6 & & 30.6 \\
\hline $\mathrm{Pt}_{2} \mathrm{FeCu}$ & & & & & 1 & & 2.8 \\
\hline$(\mathrm{Pt}, \mathrm{Pd}) \mathrm{S}$ & 1 & & & 1 & & & 5.6 \\
\hline $\mathrm{Cu}^{0}$ & \multirow{2}{*}{\multicolumn{6}{|c|}{ No. Nuggets $^{(a)}$}} & 2.8 \\
\hline Associated PGM & & & & & & & Grains $^{(b)}$ \\
\hline Os \pm Ir-Ru alloy & & & $\bullet(3)$ & & $\bullet(2)$ & $\bullet(1)$ & 6 \\
\hline Pt-Fe alloys (plates) & & & & & $\bullet(1)$ & & 4 \\
\hline $\mathrm{PtCu}$ (coats, plates) & & & $\bullet(2)$ & $\bullet(1)$ & $\bullet(3)$ & & 10 \\
\hline $\mathrm{RuS}_{2}-\mathrm{OsS}_{2}$ & & & $\bullet(2)$ & & $\bullet(1)$ & & 4 \\
\hline $\mathrm{IrAsS}$ & & & $\bullet(1)$ & & & & 1 \\
\hline $\mathrm{Cu}(\mathrm{Pt} * / \mathrm{Rh} / \mathrm{Ir})_{2} \mathrm{~S}_{4}$ & & & $\bullet(1)$ & $\bullet(1 *)$ & $\bullet(1)$ & & 3 \\
\hline PtS*-PdS & & & & $\bullet(1 *)$ & & & 5 \\
\hline $\mathrm{Au}-(\mathrm{Pd}, \mathrm{Ag})^{*}$ & & & & $\bullet(1 *)$ & & & 1 \\
\hline $\mathrm{Ag}-(\mathrm{Fe}, \mathrm{Cu})^{*}$ & & & & $\bullet(1 *)$ & & & 1 \\
\hline
\end{tabular}

(a) Number of nuggets on which these associated PGM and native metals were found.

(b) Total number of grains located (approx.).

*Attached to ilmenite grains.

could have brought alluvial PGM from elsewhere. The west slope of Mateki Ridge above the Alako is the dip slope of the layers above the PGM-bearing horizons $\mathrm{B}, \mathrm{C}$ and $\mathrm{D}$ that outcrop on the east slope of Mateki ridge. There are no tributaries or dry valleys on the west side of the ridge indicating sufficient erosion to expose the PGE-enriched layers. Therefore, simple erosion of the PGEenriched layers should only release PGM into the Big Water and cannot explain the occurrence of PGM in the Alako.

Big Water rises $5 \mathrm{~km}$ above the sampling points (Fig. 1) and flows along the eastern side of Mateki Ridge with several dry valleys cutting into the ridge. The main stream comes from the east, crossing the strike of the layered rocks including the PGM-bearing Horizon M which has an As-, Sb-, PGE-bearing mineralogy (Bowles et al., 2013). There could be some PGM input from Horizon $\mathrm{M}$ at the sampling sites but the nuggets do not show significant mineralogical differences between west bank, stream bed and east bank (Table 3) and there is no sign of As- or Sb-bearing phases. It seems likely that the majority of the PGM in Big Water are derived from the PGE-bearing horizons that follow Mateki Ridge.

\section{Mineralogy of the black sands}

The black sands are mainly composed of magnetite, ilmenite and hematite grains about 200 to 

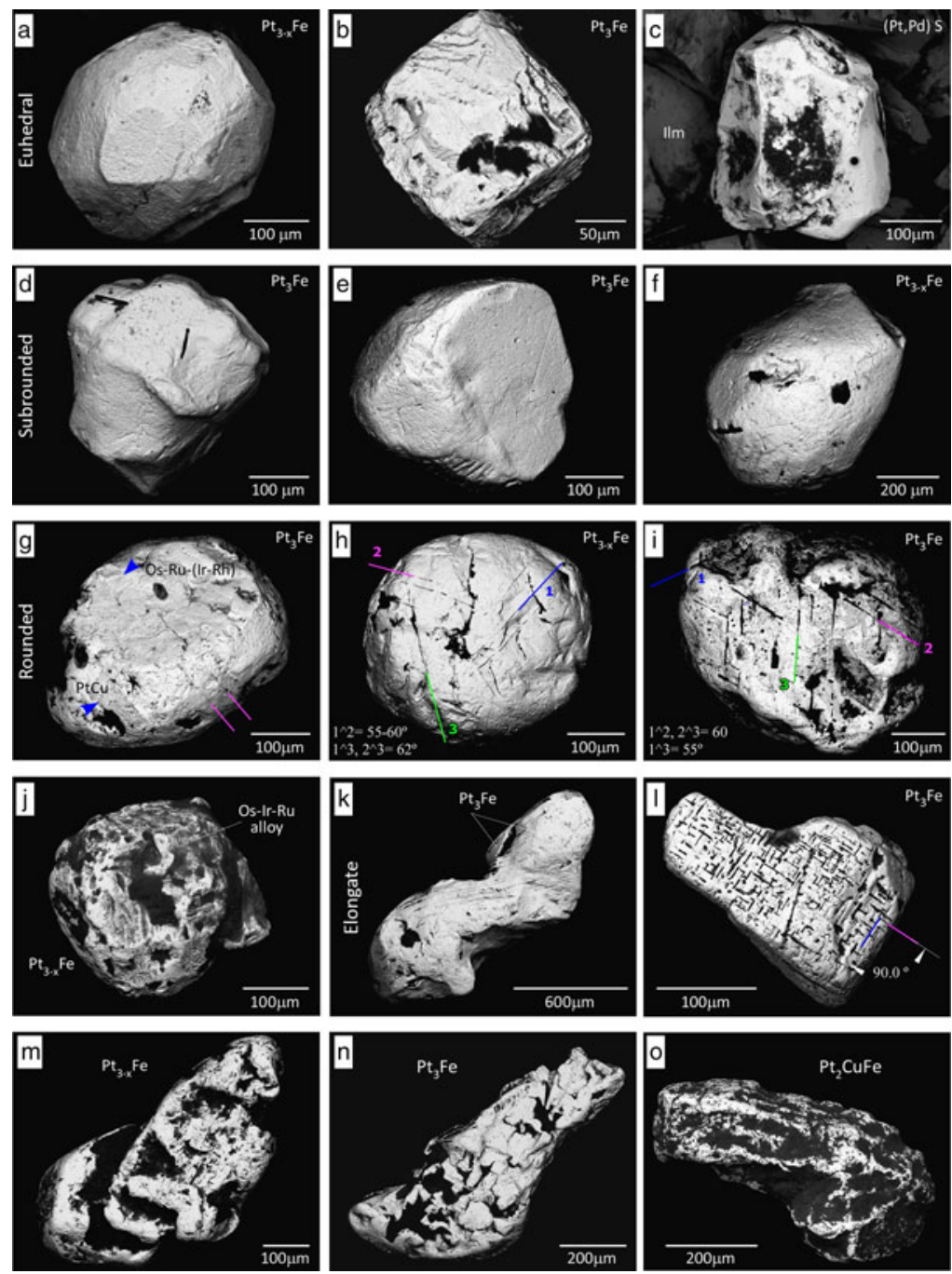

FIG. 2. Scanning electron microscope images of alluvial PGM nuggets from the Alako and Big Water, York area, Freetown. (a) Abraded $\mathrm{Pt}_{3-x} \mathrm{Fe}$ with remnants of (111) faces; $(b-c)$ euhedral isoferroplatinum $\left(\mathrm{Pt}_{3} \mathrm{Fe}\right)$ and Pd-bearing cooperite (PtS) nuggets; $(d-e)$ subhedral $\mathrm{Pt}_{3} \mathrm{Fe}$ with pits and furrows on surface, $(f)$ a more rounded $\mathrm{Pt}_{3-x} \mathrm{Fe} ;(g)$ subrounded $\mathrm{Pt}_{3} \mathrm{Fe}$ with $\mathrm{Os}$ - $\mathrm{Ru}$-Ir and hongshiite $(\mathrm{PtCu})$ plates disposed parallel to the surface; $(h-i)$ rounded $\mathrm{Pt}_{3-x} \mathrm{Fe}$ and $\mathrm{Pt}_{3} \mathrm{Fe}$ nuggets showing three sets of surface linear features; $(j)$ rusty $\mathrm{Pt}_{3-x} \mathrm{Fe}$ bearing an irregular plate of Os-Ir-Ru alloy; $(k)$ elongate $\mathrm{Pt}_{3} \mathrm{Fe}$ with fine striations covering the whole nugget; $(l)$ another elongate $\mathrm{Pt}_{3} \mathrm{Fe}$ with two sets of surface structures at right angles; $(m)$ elongate and irregular single nugget of $\mathrm{Pt}_{3-x} \mathrm{Fe} ;(n)$ elongate $\mathrm{Pt}_{3} \mathrm{Fe}$ nugget with a heterogeneous surface showing aggregates of more euhedral to irregular crystals of Pt-Fe alloys; $(o)$ tulameenite $\left(\mathrm{Pt}_{2} \mathrm{FeCu}\right) ;(p-s)$ irregular $\mathrm{Pt}_{3} \mathrm{Fe}$ and $\mathrm{Pt}_{3-x} \mathrm{Fe}$ nuggets with large PGM attached including erlichmanite $\left(\mathrm{OsS}_{2}\right)$, cuproiridsite $\left(\mathrm{CuIr}_{2} \mathrm{~S}_{4}\right)$, Os-Ir-Ru alloys, irarsite (IrAsS), osmian laurite $\left(\mathrm{RuS}_{2}\right)$ and cuprorhodsite $\left(\mathrm{CuRh}_{2} \mathrm{~S}_{4}\right) ;(t)$ irregular $\mathrm{Pt}_{3} \mathrm{Fe}$ nugget with several regular shaped depressions on the surface, a large pyritohedron of laurite is attached; (u) irregular composite nugget of $\mathrm{Pt}_{3-x} \mathrm{Fe}$ and $\mathrm{PtCu}$ displaying a lobate and irregular contact between them, where $\left(u_{1}\right)$ $\mathrm{Pt}-\mathrm{Cu}$-bearing oxides and platelets of Pt-Fe and Pt-Cu lie parallel to the surface of the nugget; $(v)$ irregular and rather porous $\mathrm{Pt}_{3-x} \mathrm{Fe}$ nugget; $(w)$ nugget of native $\mathrm{Cu}$ with cuprite $\left(\mathrm{Cu}_{2} \mathrm{O}\right)$ on the surface; $(x)$ irregular $(\mathrm{Pd}, \mathrm{Pt}) \mathrm{S}$ bearing $\mathrm{PtCu}$ platelets on surface along with large masses of Fe-Al-oxides; $(y-z)$ two examples of ilmenite (Ilm) that have small clusters of PGM (cooperite and probable malanite- $\mathrm{CuPt}_{2} \mathrm{~S}_{4}$ ), $\mathrm{Au}$ and $\mathrm{Ag}$ grains, all of them $<5 \mu \mathrm{m}$ in size attached to their surface. 

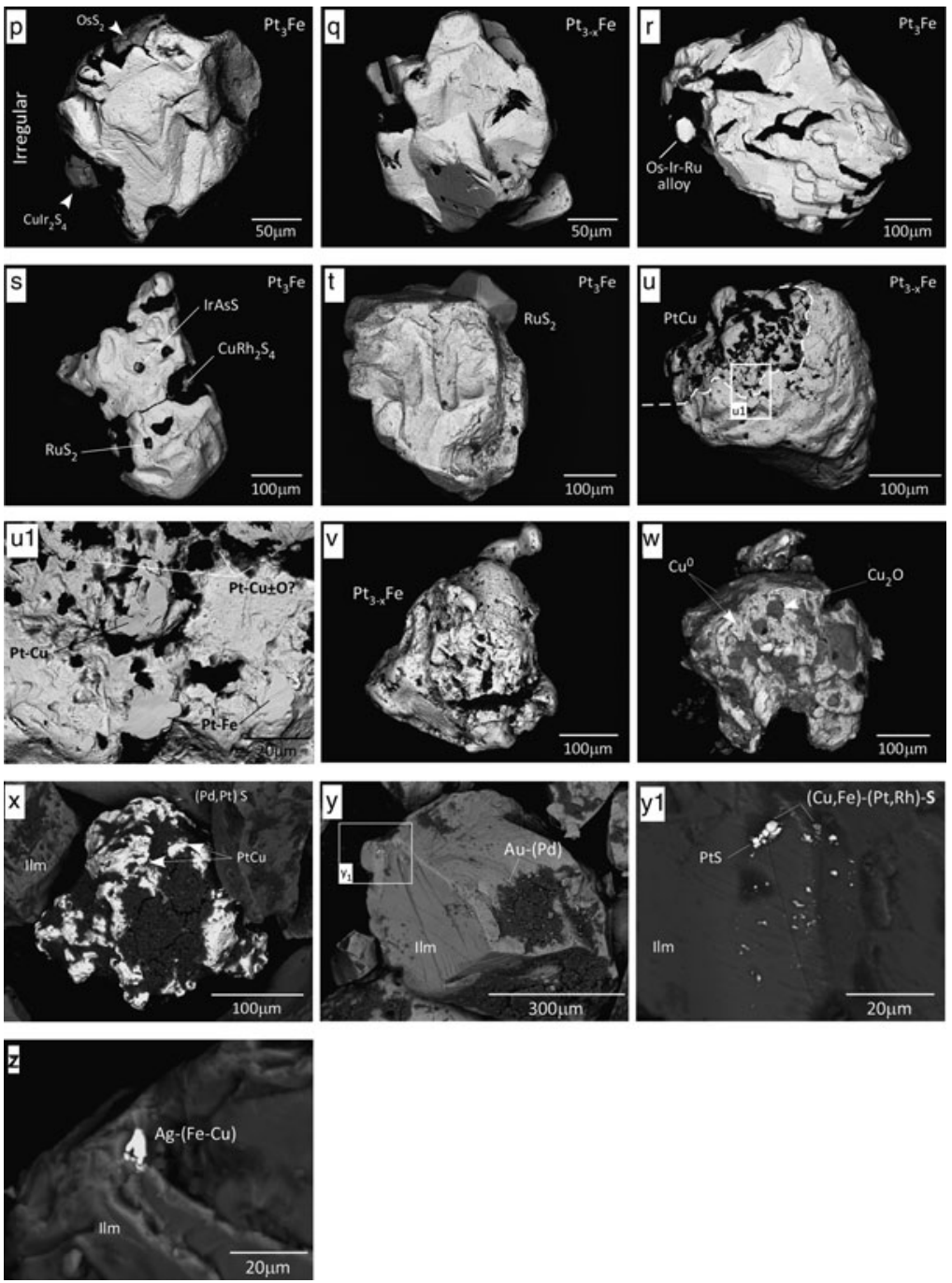

FIG. 2. Continued.

$600 \mu \mathrm{m}$ across. Titanomagnetite sometimes displays oxidation textures with ilmenite lamellae, but generally magnetite is replaced by hematite and striking martitization textures are frequently observed. In other cases magnetite shows the shrinkage cracks that are typically caused by maghemitization. Ilmenite grains occasionally show hematite exsolution and less frequently the hematite is replaced by rutile. Some ilmenite grains enclose elongate Al-spinels near their rims. Ilmenite has generally been replaced by secondary Ti-bearing oxides at the edges and along fissures or is altered to Al-bearing maghemite at the edges. Accessory phases are rutile, zircon, garnet and baddeleyite with rare galena and sphalerite. There is a lighter fraction of rounded quartz grains with rare relicts of feldspar, pyroxene and mica. Goethite and gibbsite are present as rounded aggregates enclosing minute fragments of the resistate minerals.

\section{PGM nuggets}

Thirty-six PGM nuggets have been recovered from four pit samples from Big Water and from the gravels panned from the Big Water and the Alako (Table 3). The majority (89\%) are brass 

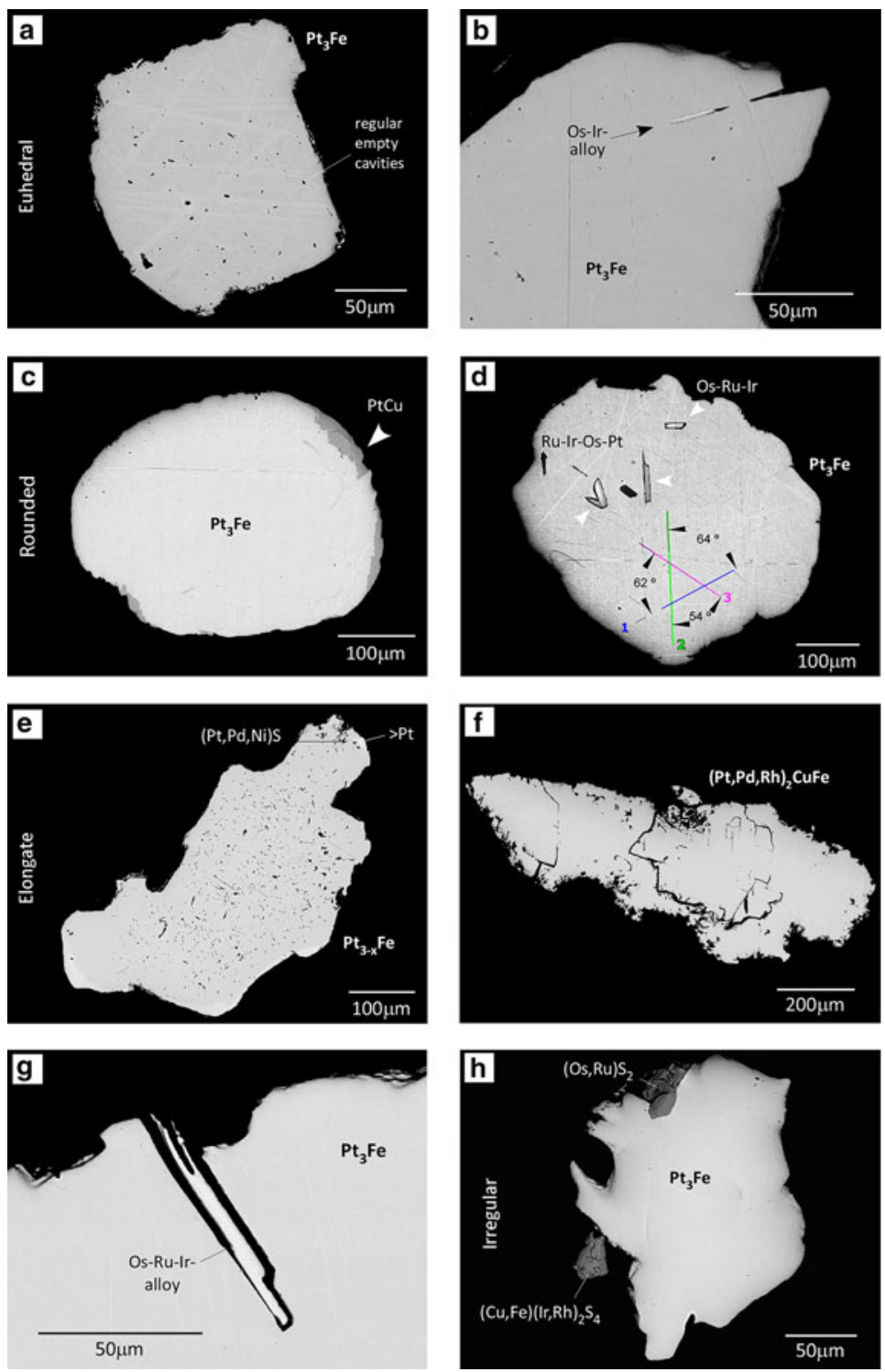

FIG. 3. Scanning electron microscope images of the polished sections of some of the alluvial PGM shown in Fig. 2. (a) Euhedral $\mathrm{Pt}_{3} \mathrm{Fe}$ nugget (Fig. $2 b$ ) showing ragged edges and regular voids; (b) a well-developed Os-Ir lamella extending to and eroded at the edge of a $\mathrm{Pt}_{3} \mathrm{Fe}$ nugget; (c) PtCu replacing $\mathrm{Pt}_{3} \mathrm{Fe}$ at the edge (Fig. $2 \mathrm{~g}$ ); (d) cluster of Os$\mathrm{Ru}$-Ir alloy inclusions (bright) with Ru-Ir-Os alloy inclusions (dark) in a $\mathrm{Pt}_{3} \mathrm{Fe}$ nugget (Fig. 2i). The inclusions follow preferred orientations which are intersecting at $55-60^{\circ}$; (e) elongate $\mathrm{Pt}_{3-x} \mathrm{Fe}$ (Fig. $2 m$ ) full of base-metal bearing Rh-S inclusions. One of the edges (top right) encloses PGE-sulfides (cooperite and braggite); $(f)$ a nugget of tulameenite (Fig. 2o) showing porous and corroded edges in section; $(g)$ thin crystal of an Os-Ru-Ir alloy that may correspond to a broken or corroded Os platelet extending to the edge of the host $\mathrm{Pt}_{3} \mathrm{Fe} ;(h)$ erlichmanite $\left(\mathrm{OsS}_{2}\right)$ and cuproiridsite $\left(\mathrm{CuIr}_{2} \mathrm{~S}_{4}\right)$ crystals at the edges of $\mathrm{Pt}_{3} \mathrm{Fe}$ (Fig. $\left.2 p\right) ;(i)$ a large platelet of Os-Ru-Ir alloy attached to $\mathrm{Pt}_{3-x} \mathrm{Fe}(\mathrm{Fig} .2 q) ;(j)$ irregular elongate $\mathrm{Pt}_{3} \mathrm{Fe}$ grain (Fig. $2 s$ ) full of varied polygonal crystals of PGM; $(k) \mathrm{Pt}_{3} \mathrm{Fe}$ with the large crystal of laurite shown in Fig. $2 t$; $(l)$ section of a composite $\mathrm{Pt}_{3-x} \mathrm{Fe}-\mathrm{PtCu}$ nugget (Fig. $2 u, u_{1}$ ) showing the irregular contact between the phases suggesting replacement by the $\mathrm{PtCu} ;(m)$ porous $\mathrm{Pt}_{3-x} \mathrm{Fe}$ nugget (Fig. $2 v$ ) hosting various Pt-Pd-alloys; $(n)$ irregular $\mathrm{Pt}_{3-x} \mathrm{Fe}$ nugget with a large crystal and lamellae of Or-Ru-Ir alloys. 

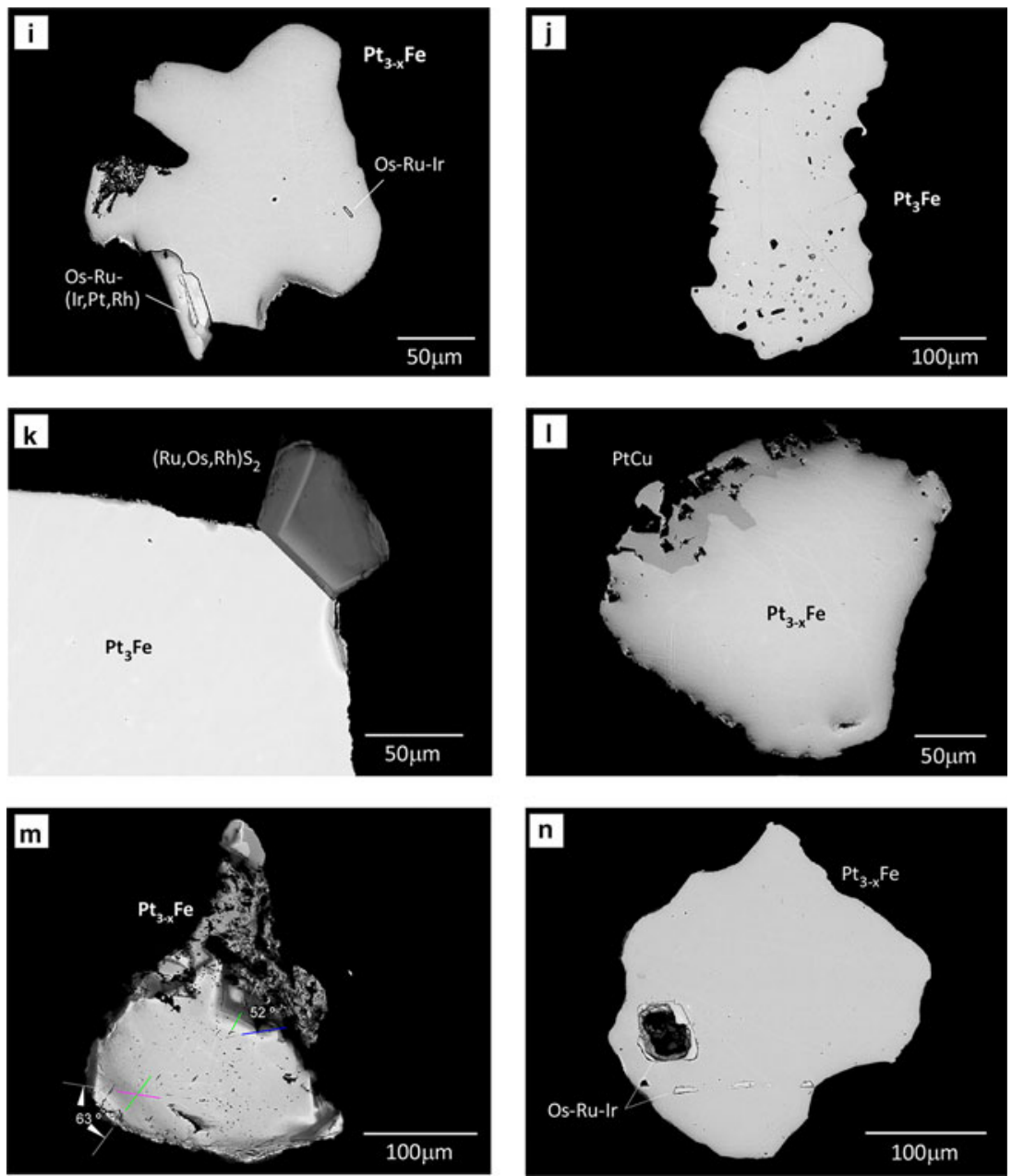

FIG. 3. Continued.

coloured Pt-Fe alloys occasionally forming composite grains with minor hongshiite $(\mathrm{PtCu})$. There is also one nugget of tulameenite $\left(\mathrm{Pt}_{2} \mathrm{FeCu}\right)$ and two nuggets of PGE-sulfides belonging to the cooperite-braggite-vysotskite series (PtS-PdS). One nugget of native $\mathrm{Cu}$ has been recovered. The nuggets are typically between 200 and $800 \mu \mathrm{m}$ across and the largest, from the panned stream concentrates, are up to $1.5 \mathrm{~mm} \times 1.4 \mathrm{~mm}$ in size.

The shape of the nuggets is variable as shown in Figs 2 and 3. Four euhedral nuggets were located (Fig. $2 a-c$ ). The nugget shown in Fig. $2 b$ is very clearly a cube with well preserved corners that have not suffered abrasion. The nugget in Fig. $2 a$ has (100) faces and five of them can be distinguished in the image. The region between the (100) faces has been abraded but there appear to be the remnants of (111) faces present. Subrounded to rounded shapes $(n=11$ grains; Fig. $2 d-j)$ or elongate shapes $(n=9$; Fig. $2 k-o$ ) are more common. Some nuggets occur as irregular grains often with multiple isolated planar surfaces $(n=12$; Fig. $2 p-x)$.

Several grains show pits and etched sub-parallel furrows on the surface (Fig. $2 e, k$ ). There are also surface linear features that either intersect at $\sim 60^{\circ}$ or $90^{\circ}$ indicating a crystallographic control (Fig. $2 h$, $i, l)$. The pattern of intersecting features maintains the same orientation across the whole surface of the nuggets, suggesting that the nuggets are probably single crystals. 


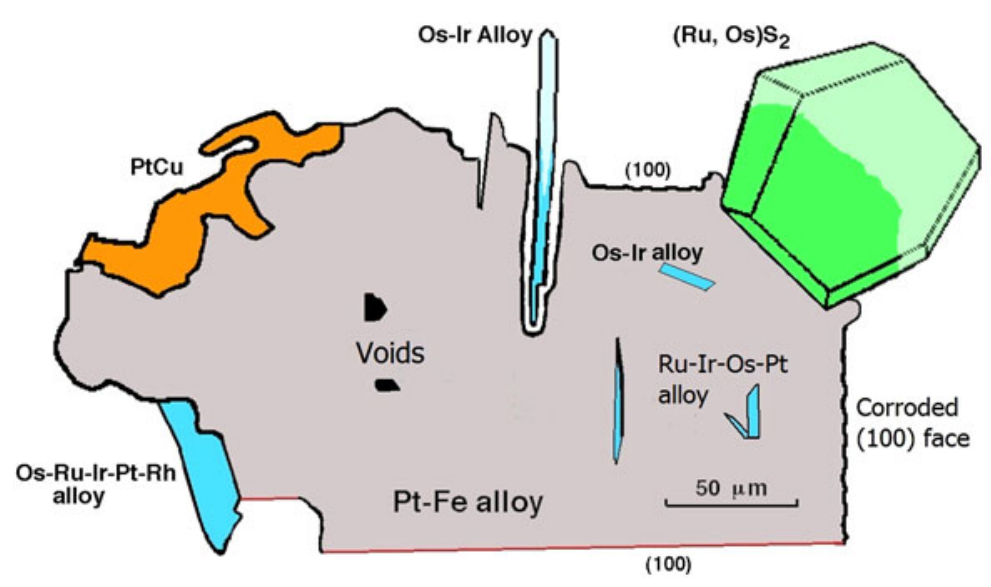

FIG. 4. Cartoon to assemble various textures of the nuggets in one diagram. The host Pt-Fe alloy (grey) may have a sculpted or euhedral outline. Laurite-erlichmanite (green) and Os-rich alloys (blue) exterior to the Pt-Fe alloy are normally euhedral. Osmium-rich alloys within the nugget are often euhedral. Alteration of the Pt-Fe alloy to hongshiite ( $\mathrm{PtCu}$, in orange) shows cuspate textures. This sketch is drawn from examples shown in Figs 2 and 3, and from Bowles $(1981,1995)$. Inclusions from the present work (Fig. $3 g, k$ ) show broken surfaces where they protrude from the host. Observations from previous work of the probable original form of these crystals are drawn with lighter tones of blue and green.

The nuggets are often partially coated by Fe- and Al-oxides or altered silicates commonly on irregular grains that are also often covered by smaller PGM grains (Fig. $2 j, p, r, s, u, x$ ).

There are many smaller PGM associated with the Pt nuggets (Table 3 ); they occur singly or as clusters on the nugget surface or within the nugget. They are also seen as free grains. Those at the nugget surface are generally larger $(0.1$ to $0.4 \times$ the diameter of the nugget) whilst those within the nuggets are micrometre sized but exhibit the same mineral assemblage. The surface PGM form irregular platelets up to $80 \mu \mathrm{m}$ across consisting of $\mathrm{Os} \pm \mathrm{Ir}-\mathrm{Ru}$-(Rh) alloys (osmium, according to the nomenclature in Harris and Cabri, 1991) as shown in Figs $2 g, j, r, 3 i$. There are smaller irregular platelets up to $20 \mu \mathrm{m}$ across of Pt-Fe and Pt-Cu alloys (Fig. $2 u, u_{1}$ ), non water worn euhedral pyritohedra of Os-bearing laurite $(\sim 130$ $\mu \mathrm{m}$ in diameter, Figs $2 t, 3 k$ ), and crystals of laurite $\left(\mathrm{RuS}_{2}\right)$, erlichmanite $\left((\mathrm{Os}, \mathrm{Ru}) \mathrm{S}_{2}\right)$, irarsite $((\mathrm{Ir}, \mathrm{Rh})$ AsS $)$, cuproiridsite and cuprorhodsite $((\mathrm{Cu}, \mathrm{Fe})(\mathrm{Ir} /$ $\mathrm{Pt}, \mathrm{Rh})_{2} \mathrm{~S}_{4}$ ) that are $\sim 50 \mu \mathrm{m}$ across (Figs $2 p, s ; 3 h$ ).

The osmium platelets can be set at a steep angle or lie parallel to the surface of the Pt-Fe host (Figs $2 j, r ; 3 b, g, i$; also Bowles, 1981, fig. 1; Bowles, 1995, figs 8, 9, 10). The laurite-erlichmanite crystals project from the surface of the Pt-Fe alloy host and are frequently euhedral (Figs $2 p, t ; 3 h, k$; also Bowles, 1981, fig. 2; Bowles, 1995, figs 1, 7;
Cabri, 1981 figs 7.9A-C and 7.26A). Cuproiridsite and cuprorhodsite (Figs $2 p, s ; 3 h$ ) may also show this relationship. In polished section the contact between the host and the associated mineral is a straight line (Fig. $3 g, h, i$ ). Examples (Fig. $3 k$ and Bowles 1995, fig. 10) demonstrate that this contact is between planar crystal faces of two crystals that grew at the same time. In some cases the host appears to have grown outwards to surround the associated mineral (Fig. $2 g, j$ and Bowles, 1995, fig. 10). A totally different relationship is seen (Fig. $3 c$, l) where hongshiite is situated along the rim of a PtFe alloy. Here the contact between the two minerals is curved or lobate and within the boundary of the whole grain. These textures suggest replacement of $\mathrm{Pt}-\mathrm{Fe}$ by $\mathrm{PtCu}$. A cartoon diagram to illustrate these relationships is shown in Fig. 4.

\section{PGM on the surface of ilmenite grains}

In a separate association, very small $(5 \mu \mathrm{m})$ PGM and native $\mathrm{Au}$ and $\mathrm{Ag}$ grains have been found attached to ilmenite grains recovered from the pits (Table 3). In one case a cluster of cooperite and malanite grains occurs on the surface of an ilmenite grain (Fig. 2y, $y_{1}$ ) and euhedral grains of Pd-Agbearing gold are also present. A grain approximating to native silver was also observed on the surface of another ilmenite grain (Fig. 2z). 


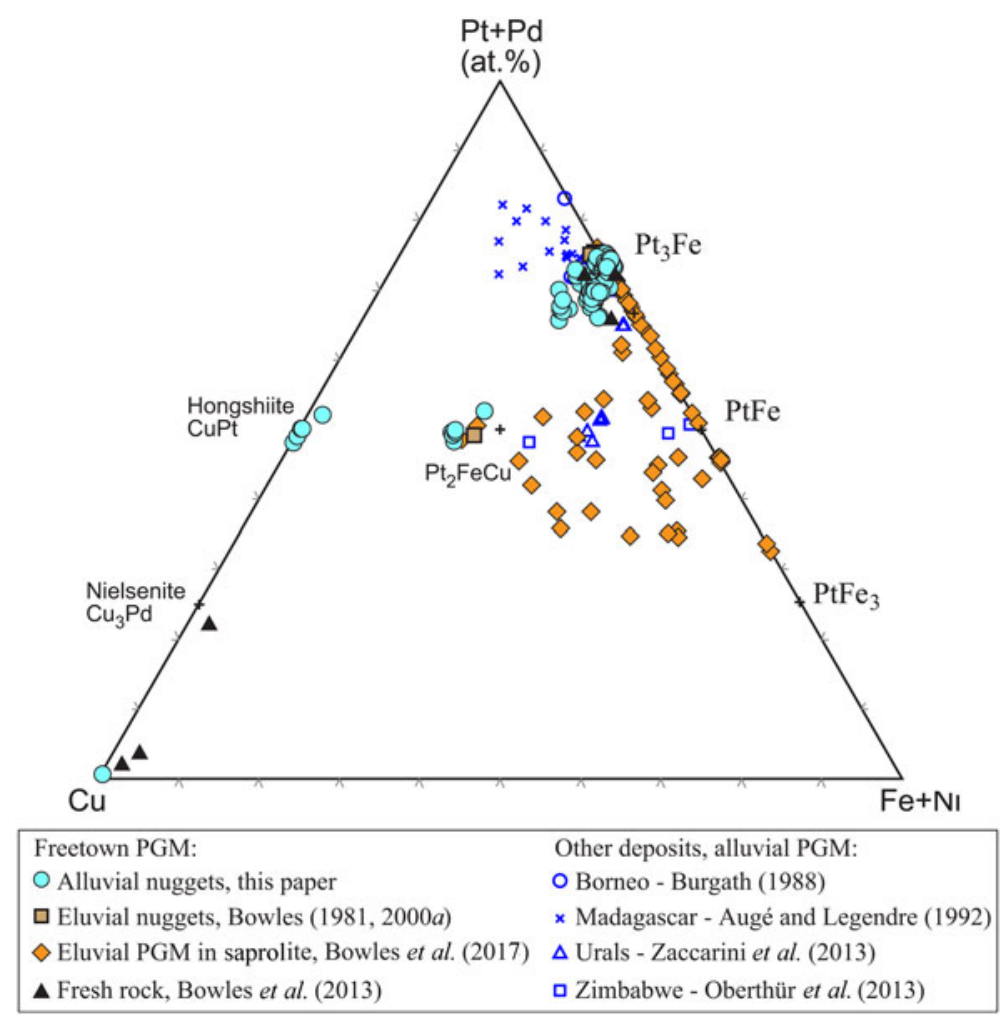

FIG. 5. The compositions of the eluvial and alluvial PGM from the Mateki area plotted on a triangular $(\mathrm{Pt}+\mathrm{Pd})-\mathrm{Cu}-(\mathrm{Fe}+\mathrm{Ni})$ diagram. Some analyses of the small eluvial PGM are qualitative. Additional data from the literature is included for comparison.

\section{Composition of the PGM nuggets}

\section{Pt-Fe alloys}

The $32 \mathrm{Pt}-\mathrm{Fe}$ nuggets recovered have a composition ranging from $\mathrm{Pt}_{3} \mathrm{Fe}$ to $\mathrm{Pt}_{2.6} \mathrm{Fe}_{1.4}$. The majority of the nuggets $(70 \%)$ have a composition close to isoferroplatinum with a general formula of $\mathrm{Pt}_{3-x} \mathrm{Fe}$ with $x=0-0.38$. Compositions are plotted in Fig. 5 and representative analyses are presented in Table 4. There is substitution of Pt by other PGE (mainly Pd with $\mathrm{Rh}$, and rarely $\mathrm{Ir}$ and $\mathrm{Ru}$ ) and $\mathrm{Fe}$ by $\mathrm{Cu}$ and, to a lesser extent, Ni. Palladium and $\mathrm{Rh}$ have been recorded in $\sim 20$ of the Pt-Fe nuggets recovered and the concentration of either is usually $<8$ at. $\%$ but rarely nuggets can contain as much as 25 at. $\% \mathrm{Pd}$ and these can contain Pd-bearing inclusions.

\section{Hongshiite (PtCu)}

Hongshiite (Fig. $2 g, u, u_{1}$ ) forms both irregular rims to six of the Pt-Fe alloys (Fig. $3 c, l$ ) and plates lying parallel to the nugget surface (Fig. $2 u_{1}$ ). The hongshiite has uniform $\mathrm{Pt}$ and $\mathrm{Cu}$ contents with occasional minor Pd (av. 1.8 at.\%), Fe (1.8 at.\%) and $\mathrm{Rh}(0.5$ at.\%) (Table 4$)$.

\section{Tulameenite}

One elongate nugget of tulameenite was found (BW6, Table 3). It is $600 \mu \mathrm{m}$ across and largely coated with patches of Al-Si-(Fe)-oxides (Fig. 2o). In section, the nugget appears slightly cracked and has very irregular and porous edges (Fig. $3 f$ ). The composition is consistent throughout $((\mathrm{Pt}, \mathrm{Pd}$, $\mathrm{Rh})_{2} \mathrm{Cu}_{1.25} \mathrm{Fe}_{0.75}$ ) having higher $\mathrm{Cu}$ than ideal tulameenite and uniform $\mathrm{Pd}$ and $\mathrm{Rh}$ contents totalling $\leq 4.0$ at.\% (Fig. 5; Table 4). Unlike the tulameenite from Guma Water (Bowles, 1981), no traces of $\mathrm{Os}$ and $\mathrm{Ru}$ were detected in this nugget.

\section{Pt-Pd sulfides}

Two nuggets belonging to the cooperite-braggitevysotskite series were located during pitting beside 
TABLE 4. Representative compositions of the Pt-nuggets and large associated PGM from energy-dispersive spectrometry.

\begin{tabular}{|c|c|c|c|c|c|c|c|c|c|c|c|c|}
\hline \multirow[b]{2}{*}{$\begin{array}{l}\text { Sample } \\
\text { Figs }\end{array}$} & \multicolumn{7}{|c|}{ Single nuggets } & \multicolumn{5}{|c|}{ Associated PGM } \\
\hline & $\begin{array}{c}\mathrm{Pt}_{3} \mathrm{Fe} \\
\text { Alako1 } \\
2 b, 3 a\end{array}$ & $\begin{array}{c}\mathrm{Pt}_{3} \mathrm{Fe} \\
\mathrm{BW} 6 \\
2 e\end{array}$ & $\begin{array}{l}\mathrm{Pt}_{3} \mathrm{Fe} \\
\mathrm{BW} 2 \\
2 s, 3 j\end{array}$ & $\begin{array}{c}\mathrm{Pt}_{3-x} \mathrm{Fe} \\
\mathrm{BW6} \\
2 q, 3 i\end{array}$ & $\begin{array}{c}\mathrm{Pt}_{3-x} \mathrm{Fe} \\
\mathrm{BW} 6 \\
2 u, 3 l\end{array}$ & $\begin{array}{c}\mathrm{Pt}_{3-x} \mathrm{Fe} \\
\mathrm{BW} 9 \\
2 m, 3 e\end{array}$ & $\begin{array}{c}\mathrm{Pt}_{2} \mathrm{FeCu} \\
\mathrm{BW} 6 \\
2 o, 3 f\end{array}$ & $\begin{array}{l}\mathrm{PtCu} \\
\mathrm{BW} 2 \\
2 g, 3 c\end{array}$ & $\begin{array}{l}\mathrm{PtCu} \\
\mathrm{BW} 6 \\
2 u, 3 l\end{array}$ & $\begin{array}{c}\mathrm{OsS}_{2} \\
\mathrm{BW} 6 \\
2 p, 3 h\end{array}$ & $\begin{array}{l}\mathrm{RuS}_{2} \\
\mathrm{BW} 2 \\
2 t, 3 k\end{array}$ & $\begin{array}{c}\text { Os-Ru } \\
\text { BW6 } \\
3 i\end{array}$ \\
\hline \multicolumn{13}{|l|}{ wt.\% } \\
\hline Pt & 90.30 & 89.51 & 88.92 & 88.12 & 85.89 & 61.43 & 72.68 & 74.98 & 74.53 & - & - & 1.55 \\
\hline $\mathrm{Pd}$ & - & - & 0.84 & - & 1.50 & 23.19 & 1.42 & - & 0.40 & - & - & - \\
\hline $\mathrm{Rh}$ & - & 1.05 & - & 1.10 & 1.08 & - & 4.47 & 0.58 & - & - & 3.74 & 1.08 \\
\hline $\mathrm{Ru}$ & - & - & - & - & - & - & - & - & - & 15.23 & 32.82 & 22.00 \\
\hline Ir & - & - & - & - & - & - & - & - & - & - & - & 14.09 \\
\hline Os & - & - & - & - & - & - & - & - & - & 53.19 & 29.00 & 60.94 \\
\hline $\mathrm{Cu}$ & 0.71 & 0.35 & 0.37 & 1.98 & 0.84 & 2.71 & 12.53 & 25.07 & 25.04 & - & - & - \\
\hline $\mathrm{Ni}$ & - & - & - & - & - & 0.57 & - & - & - & - & - & - \\
\hline $\mathrm{Fe}$ & 9.38 & 9.34 & 9.16 & 9.68 & 10.25 & 11.43 & 8.93 & - & - & - & - & - \\
\hline As & - & - & - & - & - & - & - & - & - & - & 1.12 & - \\
\hline $\mathrm{S}$ & - & - & - & - & - & - & - & - & - & 30.67 & 33.30 & - \\
\hline Total & 100.39 & 100.25 & 99.29 & 100.88 & 99.56 & 99.33 & 100.03 & 100.63 & 99.97 & 99.09 & 99.98 & 99.66 \\
\hline \multicolumn{13}{|c|}{ Atoms per formula unit } \\
\hline $\mathrm{Pt}$ & 2.88 & 2.86 & 2.88 & 2.71 & 2.66 & 1.59 & 1.89 & 0.98 & 0.98 & - & - & 0.01 \\
\hline $\mathrm{Pd}$ & - & - & 0.05 & - & 0.09 & 1.10 & 0.07 & - & 0.01 & - & - & - \\
\hline $\mathrm{Rh}$ & - & 0.06 & - & 0.06 & 0.06 & - & 0.22 & 0.01 & - & - & 0.07 & 0.02 \\
\hline $\mathrm{Ru}$ & - & - & - & - & - & - & - & - & - & 0.33 & 0.62 & 0.35 \\
\hline Ir & - & - & - & - & - & - & - & - & - & - & - & 0.12 \\
\hline Os & - & - & - & - & - & - & - & - & - & 0.61 & 0.29 & 0.51 \\
\hline $\mathrm{Cu}$ & 0.07 & 0.03 & 0.04 & 0.19 & 0.08 & 0.22 & 1.00 & 1.01 & 1.01 & - & - & - \\
\hline $\mathrm{Ni}$ & - & - & - & - & - & 0.05 & - & - & - & - & - & - \\
\hline $\mathrm{Fe}$ & 1.05 & 1.04 & 1.04 & 1.04 & 1.11 & 1.04 & 0.81 & - & - & - & - & - \\
\hline As & - & - & - & - & - & - & - & - & - & - & 0.03 & - \\
\hline $\mathrm{S}$ & - & - & - & - & - & - & - & - & - & 2.07 & 1.99 & - \\
\hline Total & 4.0 & 4.0 & 4.0 & 4.0 & 4.0 & 4.0 & 4.0 & 2.0 & 2.0 & 3.0 & 3.0 & 1.0 \\
\hline
\end{tabular}

- not detected.

Big Water (Table 3). One nugget is euhedral cooperite $300 \mu \mathrm{m}$ in diameter (Fig. 2c) containing an average of 42 at.\% Pt and 10 at.\% Pd along with low $\mathrm{Ni}$ and $\mathrm{Cu}$ contents totalling 1.5 at.\%. The other nugget is an irregular grain of braggite-vysotskite $250 \mu \mathrm{m}$ in diameter (Fig. $2 x$ ) that is partially coated by Aloxides and has small plates of hongshiite $22 \mu \mathrm{m}$ across on its surface. This nugget has an average of 34.2 at.\% $\mathrm{Pd}, 14.3$ at.\% $\mathrm{Pt}$ and minor amounts of $\mathrm{Fe}$ (1.4 at.\%), Ni (0.6 at.\%) and $\mathrm{Co}(0.3$ at.\%).

\section{Ru-Os sulfides}

Members of the laurite $\left(\mathrm{RuS}_{2}\right)$-erlichmanite $\left(\mathrm{OsS}_{2}\right)$ series occur attached to $\mathrm{Pt}_{3} \mathrm{Fe}$ nuggets from $\mathrm{Big}$ Water and none were found as discrete grains (Table 4). One example is an irregular grain of erlichmanite (Fig. $2 p$ ) whilst the other grains are laurite with variable Os content, the largest being a $50 \mu \mathrm{m}$ diameter pyritohedron (Fig. $2 t, 3 k$ ) with Os (av. 11.9 at.\%), Rh (2.3 at.\%) and minor As (0.18 at.\%).

\section{Rh, Ir, Pt base metal sulfides}

Two grains of the cuprorhodsite-cuproiridsitemalanite series were found both attached to $\mathrm{Pt}_{3} \mathrm{Fe}$ nuggets from Big Water (Table 3). One grain is about $40 \mu \mathrm{m}$ in diameter (Figs $2 p, 3 h$ ) with a composition close to the cuproiridsite $(\mathrm{Cu}, \mathrm{Fe})(\mathrm{Ir}$, $\mathrm{Rh})_{2} \mathrm{~S}_{4}$ and $\sim 20$ at.\% Ir and 8 at.\% Rh. The other grain is $30 \mu \mathrm{m}$ across (Fig. 2s) and has a composition closer to cuprorhodsite $(\mathrm{Cu}, \mathrm{Fe})(\mathrm{Rh}$, 
$\mathrm{Pt}, \mathrm{Ir})_{2} \mathrm{~S}_{4}$ with about 12 at.\% Rh, 10.5 at.\% Pt and 7.3 at.\% Ir. A platinum-rich thiospinel resembling malanite $(\mathrm{Cu}, \mathrm{Fe})(\mathrm{Pt}, \mathrm{Rh})_{2} \mathrm{~S}_{4}$ containing $\mathrm{Pt}$ (av. 17.2 at. $\%)$ and $\mathrm{Rh}(10.3$ at.\%) was found on an ilmenite surface (Fig. 2y, $y_{1}$ ).

\section{Osmium alloys}

Alloys of Os-Ru \pm Ir form part of many of the composite nuggets found in the Big Water and the Alako (Table 3). They occur as thin platelets lying either parallel to the host surface (Figs $2 g, j, 3 i$ ), or at a steep angle to the surface (Fig. 2q, r). Some of the steeply set platelets are partially contained within the nugget and extend outwards from the nugget surface where damage can occur (Fig. $3 g$ ). Inclusions of Os-Ru \pm Ir alloys are seen in cross sections and in Big Water both Os-Ru-Ir alloy inclusions and Ru-Ir-(Os-Pt, Rh) alloys occur in the same host (Fig. 3d).

The osmium-rich alloys contain variable $\mathrm{Ru}(0-$ 37 at.\%) and Ir (6-21 at.\%), and minor Rh, Pt and As totalling up to 4.8 at.\%. About $70 \%$ of the Osalloys analysed contain higher Ru than Ir regardless of the relation to their hosts. Similar variable compositions were reported for the hexagonal platelets of Os on the surface of the Guma Water nuggets (Bowles, 1981).

\section{Discussion}

Contrasting explanations have been offered for the occurrence of alluvial PGM nuggets: (1) Nuggets derived from the erosion of igneous rocks can travel with soil that is washed down slope and into rivers to be trapped in patches of gravel that form a natural riffle. The PGM are unaltered, except for surface abrasion (Cabri and Harris, 1975; Cabri and Laflamme, 1997; Cabri, 1981; Cabri et al., 1981, 1996; Malitch and Thalhammer, 2002; Weiser 2002). (2) Weathering of the rocks, aided by organic acids in the soil, breaks down the primary PGM releasing the PGE which move through the soil in solution. Soil close to a river is a location where the contrast between the $\mathrm{Eh}$ and $\mathrm{pH}$ of the soil and the river is highest. A large change from acidic to neutral conditions accompanied by a reduction in Eh can cause precipitation of the PGE allowing the growth of nuggets. This growth may be aided by bacterial activity (Reith et al., 2016). Areas of tropical weathering with high rainfall and abundant organic material seem to be where neoformation can occur. The distinctive mineralogy (mineral assemblage, size, composition and surface features) of alluvial PGM led to proposals of a neoform origin for such PGM. This view has been taken during studies in Minas Gerais, Brazil (Hussak, 1906; Cassedanne and Alves, 1992; Cabral et al., 2007), Yubdo, Ethiopia (Ottemann and Augustithis, 1967; Augustithis, 1998), the Witwatersrand reefs and the Bushveld Intrusion, South Africa (Cousins, 1973; Cousins and Kinloch, 1976), and for the Freetown Peninsula in Sierra Leone (Bowles, 1981, 1986, 1988, 1995).

The alteration of primary PGM may involve several stages during both serpentinization and weathering (Prichard et al., 1994; Wang et al., 2008; Aiglsperger et al., 2017) leading to the formation of oxidized PGM. The Great Dyke, Zimbabwe (Locmelis et al., 2010) and the Aguablanca deposit, Spain (Suárez et al., 2010) offer notable examples. The oxidized PGM are then lost during the transition from PGM in soils or laterites close to the source forming a Pt-alloy dominated placer PGM as demonstrated by Oberthür and Melcher (2005) for the oxidized Main Sulfide Zone and placer PGM in the Great Dyke. The study of PGM in fresh rocks and closely associated saprolite in the Freetown area (Bowles et al., 2017) has shown that the primary PGM have been destroyed by weathering. This has released the PGE which have moved separately through the saprolite.

The processes postulated for PGM neoformation include: (1) long term weathering in an area that has, or has had, a warm climate and high rainfall; (2) destruction of the primary PGM and transport of the PGE in solution; (3) organic compounds, such as humic or fulvic acids that are abundant in tropical rain forest soils appear likely to be involved in solution and transport of the PGE; (4) differential movement of the PGE in solution; (5) concentration of the least mobile PGE in soils close to the rivers, the more mobile PGE (especially Pd) being carried away in solution by the rivers; (6) accretion of the remaining PGE to form a new PGM assemblage; possibly where there is a change in $\mathrm{Eh}$ and $\mathrm{pH}$ conditions favourable for deposition; and (7) bacterial action may assist, or be responsible for, the PGM growth.

The main evidence that PGM grow in situ as neoforms is that they comprise a different mineral assemblage from the PGM in the source rocks. The differences are: (1) PGE arsenides, tellurides and sulfides present in the host rocks become less abundant or disappear completely from the alluvial suite; Pt-Fe alloys including tulameenite, Os-Ir 


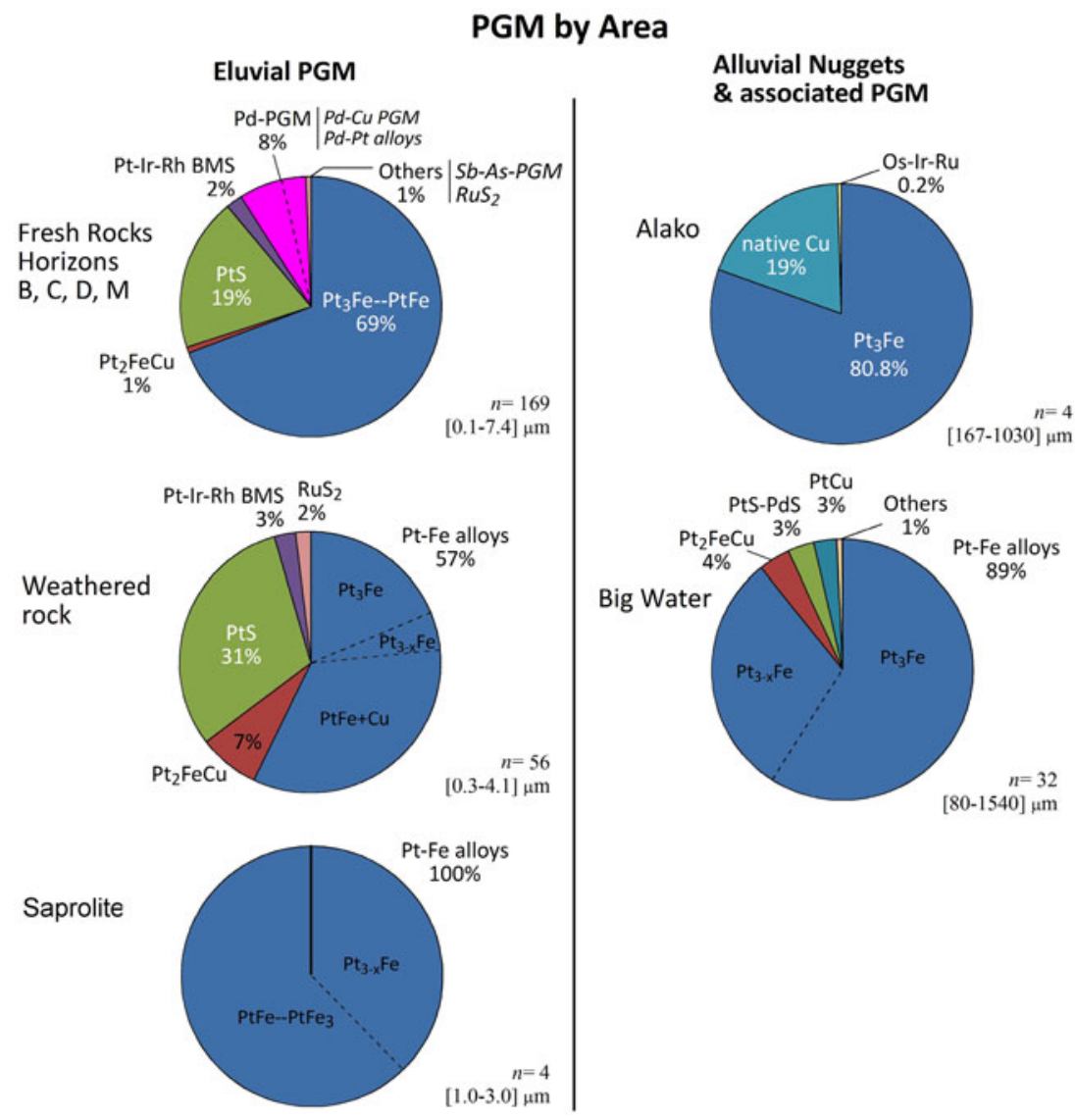

FIG. 6. Pie charts showing the changes in the Freetown PGM from the fresh source rocks to the laterite (Bowles et al., 2013, 2017) and to the alluvial deposits in the Alako and Big Water streams. BMS = base metal sulfides, $n=$ number of PGM grains and their size range.

alloys and laurite-erlichmanite become more abundant; (2) oxidized PGM appear in weathered or oxidized rocks. Cloudy, porous or filamentous altered PGM may also be present; (3) there is a loss of the more soluble Pd which is present in the host rocks, but much less abundant in an alluvial mineral suite; (4) there is a considerable difference in size (typically three orders of magnitude) between micrometre-sized PGM in the host rocks and millimetre-sized PGM in the alluvial suite; (5) some PGM in an alluvial suite show delicate crystal features that would not survive mechanical transport, these features include dendritic growths, perfect crystal faces and perfect edges and corners between crystal faces. The corners are the most susceptible to mechanical damage and the presence of undamaged corners provides convincing evidence for the absence of abrasion. The dendritic
PGM are not known to occur in the host rocks. (6) There is over plating of mineral faces, colloform, cyclic and fibrous textures not characteristic of PGM in the host rocks.

Examples of alluvial PGM showing these textures have been described by Oberthür et al. (2003, 2013); Zaccarini et al. (2013); Bowles (1981,1986,1995); Cabral et al. $(2007,2008)$ and Burgath (1988).

Some workers have pointed out that the question of the smaller grain size in the host rocks compared to the grain size of the alluvial PGM could be due to sampling. For a given grade, small grains are more numerous and more likely to be encountered by chance in a polished surface than large grains. It has been suggested, therefore, that the large grains are present in the rocks but are not detected. Indeed Oberthür et al. (2003) have shown that larger PGM 

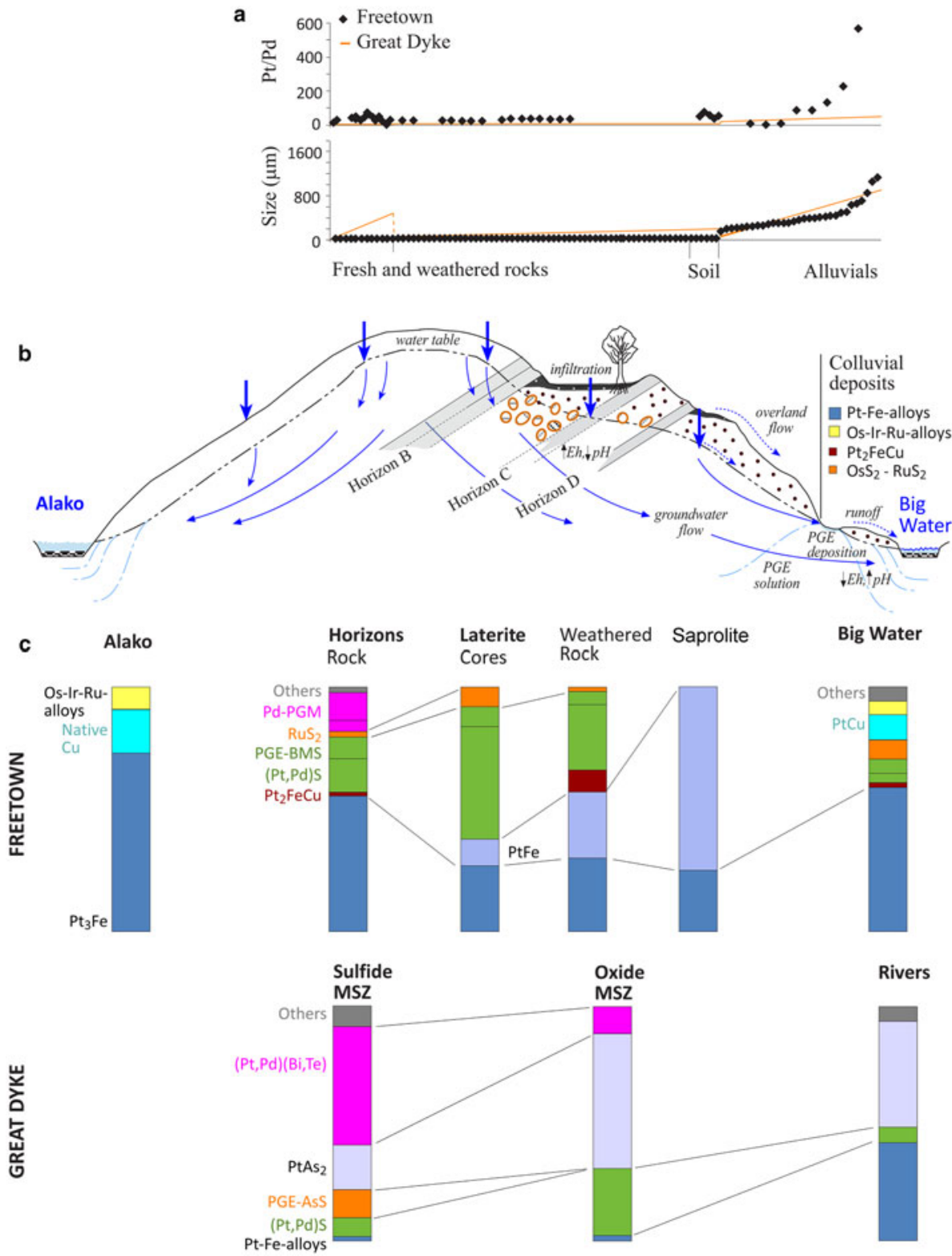

FIG. 7. The mineralogical evolution in the PGM assemblage from rock through the weathering profile to alluvial deposits. (a) The variation in $\mathrm{Pt} / \mathrm{Pd}$ ratio and grain size for the Freetown examples described here and comparable PGM from the Great Dyke, Zimbabwe (Oberthür et al. 2003). (b) The possible processes involved in the alluvial concentration of PGM in the rivers. $(c)$ Freetown mineral assemblage from the PGE-bearing primary rocks through weathered rocks, soils to alluvial deposits in the rivers. The evolution of the PGM from the Great Dyke, Zimbabwe (Oberthür et al. 2013) is shown for comparison. BMS = base metal sulfides, MSZ = main sulfide zone. PGM shown by number of occurrences found.

are difficult to locate but do occur in the Main Sulfide Zone (MSZ) of the Great Dyke, Zimbabwe. Large Pt-Fe aggregates do occur in the rocks of the Nizhni Tagil complex and the Vetnaya-Vyvenka
Belt in Russia, and the Alto Condoto complex in Colombia (Duparc and Tikonowitch, 1920; Cabri and Genkin, 1991; Salinas et al., 1992; Tistl, 1994; Zaitsev et al., 1998). Where such large nuggets 
occur in the host rocks they can unquestionably be released by weathering. It has also been suggested that perfectly crystallized or delicate alluvial grains could have been transported within a protecting rock matrix from which they have recently been released (e.g. Hagen et al., 1990, Weiser and Bachmann, 1999; Cabri et al., 1996). Inclusions of PGM and other minerals found in the alluvial nuggets such as chromite, silicates, sulfides or composite glass-silicate inclusions (e.g. Nixon et al., 1990; Johan et al., 1990; Augé and Legendre, 1992) are taken to indicate a primary origin for the inclusions and, therefore, the nuggets.

Although growth of placer PGM appears to be favoured by a warm wet climate and a long period of weathering, the dissolution of igneous PGM, their transport in solution and growth of the PGM in the placer could be relatively rapid. Vehicle catalytic converters have been in use for $<40$ years but particulate Pt and Pd catalytic converter fragments occur in road dust (Prichard and Fisher, 2012) and are concentrated in nearby acidic stream sediments (Prichard et al., 2009). In the water courses the PGE can become bioavailable after reaction with artificial additives (phosphates from fertilisers, $\mathrm{NaCl}$ from road de-icing) or natural organic compounds (especially citrates and fulvic acids, Pawlak et al., 2014). Bowles et al. $(1994 b, 1995)$ examined the relevance of the organic acids present in soils to the solution, transport and deposition of the PGE. Experiments showed that organic acids can take Pt into solution from fine-grained PtS in as little as 393 days. The laboratory experiments on bacterial growth of PGM by Reith et al. (2016) were conducted over 112 days. This is particularly significant because purely inorganic growth at low temperatures is likely to be very slow. The evidence indicates that the dissolution of igneous PGM, their transport in solution and growth of the PGM in the placer could be rapid.

Recent studies have very reasonably shown that alluvial PGM assemblages contain components derived by both mechanical means and by PGM alteration (e.g. Goodnews Bay, Alaska, Mardock and Barker, 1991; Eastern Bushveld, South Africa, Melcher et al., 2005; Great Dyke, Zimbabwe, Oberthür et al., 2002, 2003, 2013; Uktus, Central Urals, Zaccarini et al., 2013).

\section{Evolution of the PGM in the York area, Freetown}

Lithogeochemical and geomagnetic surveys associated with the present study have not encountered any anomalies in the rocks or soils indicating PGMbearing horizons within the catchment areas of the streams examined in addition to those already reported (Bowles, 2000b; Bowles et al., 2013). Repeated assays of samples, of splits from those samples, and of repeated samples from the same outcrops show consistent results. This shows that the Freetown primary PGM grain size in the rocks is clearly small with no indication in the rocks of a 'nugget effect'.

The PGM assemblage shows a development from the source rock through the saprolite to the alluvial deposits (Figs. 6,7) with the source rocks dominated by $\mathrm{Pt}-\mathrm{Fe}$ alloys $\left(\mathrm{Pt}_{3} \mathrm{Fe}, \mathrm{PtFe}\right)$ and cooperite (PtS) with minor Pt-Rh-Ir base metal sulfides, $\mathrm{Pd}-\mathrm{Cu}$ minerals, laurite, tulameenite, PdPt alloys and scarce Pt-arsenides and Ptantimonides. The weathered rocks contain oxidized PGM (Bowles et al., 2013, 2017) which marks the first stage of weathering. In more weathered rocks the PGM assemblage is dominated by $\mathrm{Pt}_{3} \mathrm{Fe}-\mathrm{PtFe}$ and $\mathrm{Pt}_{2} \mathrm{FeCu}-\mathrm{Pt}(\mathrm{Fe}, \mathrm{Cu})$ compositions and $\mathrm{PtS}$. The alloys show a wider range of compositions than those in the source rocks. Sulfides rich in Pt-Rh and osmian laurite remain as accessory minerals, but Pd-PGM are absent suggesting that both $\mathrm{Pd}$ and $\mathrm{Cu}$ are dispersed. Within the saprolite only a few $\mathrm{Pt}_{3-x}$ $\mathrm{Fe}-\mathrm{PtFe}_{3}$ alloys seem to survive (Fig. 6). Weathering of the PGM would enable PGE-bearing solutions to drain towards both Big Water and the Alako resulting in a similar alluvial PGM assemblage in both rivers (Figs. 6, 7).

The alluvial PGM nuggets are predominantly PtFe alloys mainly of $\mathrm{Pt}_{3} \mathrm{Fe}$; disordered $\mathrm{Pt}_{3-x} \mathrm{Fe}$ is also present with minor tulameenite and there is an infrequent occurrence of native copper. The PtFe in the weathered rocks does not appear in the alluvium. The Pt-Fe nuggets are often partly replaced by hongshiite $(\mathrm{PtCu})$. This may be part of a relationship between hongshiite and the Pt-Fe alloys that has been recorded from Brazil where hongshiite has been further altered to native platinum (Kwitko et al., 2002; Cabral et al., 2008). Members of the cooperite-vysotskite series (PtS-PdS), laurite and erlichmannite also appear as large, single grains in the alluvium. Less abundant phases $(<16 \%$ of the total number of PGM located) are the PGM and native metal grains that occur enclosed in the Ptnuggets or more rarely, on the surface of ilmenite (Fig. 2y, $z$; Fig. 3). A comparable story is told by the weathered rocks of the Great Dyke, Zimbabwe where PGE bismuthotellurides and sulfarsenides in the MSZ in fresh rock underground and the oxidized PGM in the oxidized ores are all missing in the alluvium. Alloys of Pt-Fe that form a minor 
proportion of the MSZ and the oxidized MSZ are much more abundant in the alluvial nuggets together with sperrylite, cooperite, braggite, laurite, rare $\mathrm{Pd}-\mathrm{Sb}-\mathrm{As}$ compounds, and Os-Ir-Ru alloys (Oberthür et al., 2003, 2013).

The Freetown mineral assemblage reflects both $\mathrm{Pt}$ and Pt, Ir, Os and Ru enrichment down slope, as observed in placer PGM deposits worldwide (Weiser, 2002). It is the loss of Pd that is the most notable especially in the alluvial deposits. In the panned samples, it is evident that the $\mathrm{Pt} / \mathrm{Pd}$ ratio is highest in those samples that show the highest Pt. In samples rich in Pt where Pd was below detection the $\mathrm{Pt} / \mathrm{Pd}$ ratios can be even higher (Table 1). These samples appear to be the most evolved and are found in natural traps in the stream bed where the course of the stream is level and the water is moving slowly.

\section{Size}

The alluvial nuggets in Big Water and Alako streams are in the same size range as the colluvial PGM in Guma Water (maximum nugget size $2 \mathrm{~cm}$ ). There is a sharp increase in size from a maximum of $7 \mu \mathrm{m}$ for the PGM in the rocks and the laterite to the placers examined in this study. The nuggets reported here have a maximum size of $1.5 \mathrm{~mm}$ but larger nuggets (up to $2 \mathrm{~cm}$ ) have been reported by earlier workers (Pollet, 1931). For example, laurite is $<1 \mu \mathrm{m}$ across in the rock but occurs as $1 \mathrm{~mm}$ sized euhedral crystals downslope. The Os alloys, not found in the rocks, are typically $50 \mu \mathrm{m}$ across in the alluvium with occasional examples up to $80 \mu \mathrm{m}$ across. The three orders of magnitude difference between the PGM in the alluvium and the source rocks contributes to the contrast between the mineral assemblages.

In the Big Water small PGM $(0.6-5 \mu \mathrm{m})$ have also been found during this study with grains of gold and silver forming clusters on ilmenite. Ilmenite-rich black sand concentrates from the artisanal workings were assayed to give $240 \mathrm{~g} / \mathrm{t} \mathrm{Pt}$ metal and the slimes, after titanium pigment preparation, gave about $400 \mathrm{~g} / \mathrm{t}$ Pt (Pollet, 1931) which suggests that these small PGM may be quite common in the stream black sands. They are the same size as the PGM in the igneous rocks and include cooperite and malanite so they may be primary PGM but they may equally well represent the early stage of nugget growth.

\section{Shape}

The Big Water and Alako are rejuvenated streams with extensive stretches of water moving quickly among rocks, an environment where abrasion and rounding of nuggets would be expected. The presence of euhedral nuggets and nuggets with well-preserved crystal faces indicates either that their source is very close, or that they have grown in situ. Some nuggets display clear hexagonal and triangularshaped depressions (Fig. 2i, $p, q, t$; Fig. 3b) suggesting a recent loss of attached euhedral grains. Other surface inclusions have survived abrasion, for example a large pyritohedron of laurite (Fig. $3 k$ ) and an Os platelet (Fig. $3 i$ have been damaged). The irregular surface of some PtFe alloys also suggests some erosion has occurred as illustrated in Fig. 4.

\section{Pt-Fe alloy compositions}

Pt-Fe alloys with compositions approximating to $\mathrm{Pt}_{2} \mathrm{Fe}$ have been reported previously especially from placer deposits. Some examples are the Chocó region, Colombia (Cabri et al., 1996); the Aikora River Area, Papua New Guinea (Weiser and Bachmann, 1999); the Great Dyke (Oberthür et al., 2003, 2013); British Columbia, Canada (Barkov et al., 2005); the Urals (Malitch and Thalhammer, 2002; Evstigneeva, 2009; Zaccarini et al., 2013) or Yubdo (Evstigneeva, 2009). Malitch and Thalhammer (2002) and Evstigneeva (2009) discuss in detail whether a composition near $\mathrm{Pt}_{2} \mathrm{Fe}$ represents a new mineral phase, a fine intergrowth of $\mathrm{PtFe}$ and $\mathrm{Pt}_{3} \mathrm{Fe}$ (as suggested by Zhernovsky et al., 1985) or a disordered structure that is stable under particular conditions. The majority of the grains examined using X-ray diffraction consisted of a disordered cubic phase but the studies also confirmed a micrometric intergrowth in two grains from the Nizhni Tagil placers.

It seems probable that the Freetown Pt-Fe alloy with a composition near to $\mathrm{Pt}_{2} \mathrm{Fe}$ is cubic and is similar to cubic tetraferroplatinum $\left(\mathrm{Pt}_{3} \mathrm{Fe}\right)$ but containing more $\mathrm{Fe}$ with some degree of disordering of the structure. It should probably be described as $\mathrm{Pt}_{3-x} \mathrm{Fe}$ where $x=0.16-0.38$ in the alluvial nuggets. There is a larger range of disordering in the weathered Pt-Fe alloy where $x=0.02-0.58$ (Bowles et al., 2017).

The existence of the disordered phases with a range of compositions is relevant to consideration of the genesis of these PGM. At high temperature, with greater mobility of the metals, there is a preference towards forming minerals with stoichiometric compositions having a restricted compositional range and an ordered structure. The inference that can be made from the presence of an almost 
continuous range of compositions, leading to the formation of disordered phases, is that formation occurred under conditions of restricted mobility as implied by a lower temperature.

The compositions of Pt-Fe alloys from similar localities are plotted in Fig. 5. Some of the Uralian nuggets described by Zaccarini et al. (2013) have isoferroplatinum-type solid cores $\left(\mathrm{Pt}_{3-x} \mathrm{Fe}\right)$ surrounded by porous $\mathrm{PtFe}$. The $\mathrm{PtFe}$ in turn includes minute particles with a transitional, $\mathrm{Pt}_{3-x}(\mathrm{Fe}, \mathrm{Cu})$ composition $(x \leq 0.35)$ that contain a higher basemetal content than either the alluvial grains from Freetown or from the Great Dyke (Oberthür et al., 2013). A minority of grains examined in the Uktus complex and Great Dyke have Pt/BM ratios close to 1 that represent solid solutions of $\mathrm{PtFe}$ and $\mathrm{Pt}_{2} \mathrm{FeCu}$. These all fall in the same field as the Pt-Fe-Cu alloys in the Freetown laterite (Fig. 5). In other areas such as Borneo and Madagascar (Burgath, 1988; Augé and Legendre, 1992) the alloy compositions occupy the Pt-rich part of the system.

\section{Conclusions}

The suite of alluvial PGM identified in this study comprises mainly $\mathrm{Pt}_{3} \mathrm{Fe}$ to $\mathrm{Pt}_{3-x} \mathrm{Fe}$ and a lesser proportion of tulameenite and PtS-PdS nuggets. Large crystals associated with the nuggets are Os-Ir-Ru alloys, laurite-erlichmanite and PGE base-metal sulfides (e.g. cuprorhodsite and cuproiridsite). The presence of tulameenite and native copper as individual nuggets and hongshiite alteration of the rims of Pt-Fe alloy is an aspect of the involvement of $\mathrm{Cu}$ in the development of the nuggets. A late generation of Pt-enriched isoferroplatinum is observed on a few nugget surfaces. Some alluvial PGM such as tulameenite or Ptsulfides can contain higher Pd than their counterparts in the rocks. This denotes changes in the mineralogy and geochemistry between the primary and alluvial PGM in Freetown.

The significant points are:

\section{Assemblage}

There is a distinctive difference between the PGM assemblage in the fresh rocks and the alluvium. Cooperite, abundant in the fresh rocks, is less abundant in the streams whereas Pt-Fe alloys form a much larger proportion of the alluvial mineral suite. Hongshiite appears as an alteration to the alluvial Pt-Fe alloys and tulameenite is more abundant. Palladium minerals in the fresh rocks are not encountered in the alluvium.

\section{Oxides}

Oxidized PGM in the weathered rocks (Bowles et al., 2013, 2017) are a transitional stage in the alteration of the primary PGM and the formation of the placer nuggets. Their fragile textures indicate that they are the result of alteration of primary PGM and mobility of PGE.

\section{Disordering}

The Pt-Fe alloys in the weathered rocks show an almost continuous range of composition from $\mathrm{Pt}_{3} \mathrm{Fe}$ to $\mathrm{PtFe}$ and nearly $\mathrm{PtFe}_{3}$, indicating varying degrees of disordering due to low-temperature alteration. The alluvial Pt-Fe nuggets are closer to $\mathrm{Pt}_{3} \mathrm{Fe}$.

\section{Palladium}

There is a significant loss of Pd relative to Pt. Ratios of $\mathrm{Pt} / \mathrm{Pd}$ of $<75$ in the host rocks rise to $100-500$ in the alluvial deposits demonstrating the greater mobility of Pd in solution.

\section{Copper}

Some Pt-Fe alloys in the placers contain a small proportion of $\mathrm{Cu}(0.3-2.7 \mathrm{wt} . \%)$ that increases the compositional variability and degree of disorder. Tulameenite, hongshiite and native $\mathrm{Cu}$ are present and appear to be a part of the involvement of $\mathrm{Cu}$ with some Pt-Fe nuggets being replaced by hongshiite at the edges. Apart from the presence of smaller grains of tulameenite, these features are not encountered in the fresh rocks.

\section{Size}

There is a three-orders of magnitude difference in size between the PGM seen in the fresh rocks compared with the larger alluvial mineral suite.

\section{Delicate crystals}

The delicate and well-preserved crystal features of some nuggets suggest a local origin; damaged nuggets have had a longer residence time in the rivers.

\section{Organic coating}

The coating of organic material on the nuggets is evidence of an association between the nuggets and organic material and may indicate involvement of organic material or bacterial action during formation of the nuggets.

\section{PGM on ilmenite}

Fine-grained PGM and grains of gold and silver occurring on the surface of ilmenite correspond to 
historic reports of an association of PGE with ilmenite in the rivers and may reveal initial stages of nugget growth.

\section{Drainage}

The presence of PGE-enriched horizons only cropping out in the Big Water drainage basin suggests that the PGE required to form the nuggets in both the Big Water and Alako streams were derived from PGE-bearing solutions draining both sides of the Mateki ridge rather than by mechanical erosion.

Taken together these points clearly indicate neoformation of the nuggets within the saprolite and alluvium after leaching of the PGE from the source rocks and transport of the PGE in solution. They are not indicative of derivation of all of the nuggets by erosion and mechanical transport.

\section{Acknowledgements}

This work has been made possible by the technical support of Drs. J. Rodríguez, R.S. García, J. Sangüesa, M. Sánchez-Lorda (SGIker, UPV/EHU) and generous funding for SS from the Department of Education, Universities and Research of the Basque Government (Refs. BFI-2011-254, IT762-13). Our manuscript was improved by the helpful advice of two reviewers who wish to remain anonymous. The panning and pitting were done by the people of York, Sierra Leone who we thank for their cheerful efforts.

\section{References}

Aiglsperger, T., Proenza, J.A., Zaccarini, F., Lewis, J.F., Garuti, G., Labrador, M. and Longo, F. (2015) Platinum group minerals (PGM) in the Falcondo Nilaterite deposit, Loma Caribe peridotite (Dominican Republic). Mineralium Deposita, 50, 105-123.

Aiglsperger, T., Proenza, J.A., Font-Bardia, M., BaurierAymat, S., Galí, S., Lewis, J.F. and Longo, F. (2016) Supergene neoformation of Pt-Ir-Fe-Ni alloys: multistage grains explain nugget formation in Ni-laterites. Mineralium Deposita, Published on-line 12 November 2016, https://doi.org/10.1007/s00126-016-0692-6

Aiglsperger, T., Proenza, J.A., Galí, S., Rius, J., Longo, F. and Domènech, C. (2017) The supergene origin of ruthenian hexaferrum in Ni-laterites. Terra Nova. 29, 106-116. Published on-line 12 March 2017, https:// doi.org/10.1111/ter.12254

Augé, T. and Legendre, O. (1992) Pt-Fe nuggets from alluvial deposits in Eastern Madagascar. The Canadian Mineralogist, 30, 983-1004.
Augustithis, S. (1998) Platinum nuggets formation in laterites. Pp. 221-224 in: International Platinum. (P.N. Laverov and V.V. Distler, editors). Theophrastus Publications, St. Petersburg, Athens.

Barber, M.J. (1962) A Report on the Prospecting for Gold, Platinum and Molybdenum Carried Out During 196162 on Behalf of the Sierra Leone Government. Sierra Leone State Development Co Ltd Freetown. 39 pp.

Barkov, A.Y., Fleet, M.E., Nixon, G.T. and Levson, V. (2005) Platinum-group minerals from five placer deposits in British Columbia, Canada. The Canadian Mineralogist, 43, 1687-1710.

Belete, K.H., Mogessie, A., Hoinkes, G. and Ettinger, K. (2000) Platinum-group minerals and chrome-spinels in the Yubdo ultramafic rocks, Western Ethiopia. Journal of African Earth Science, 30, 10-11.

Belete, K.H., Mogessie, A. and Bowles, J.F.W. (2002) Platinum-group minerals in the Alaskan type maficultramafic intrusion of the Yubdo area, Western Ethiopia. Abstract, $9^{\text {th }}$ International Platinum Symposium. 3p, https://nicholas.duke.edu/people/ faculty/boudreau/9thPtSymposium/Belete_Abstract.pdf

Bowles, J.F.W. (1981) The distinctive suite of platinumgroup minerals from Guma Water, Sierra Leone. Bulletin de Minéralogie, 104, 478-483.

Bowles, J.F.W. (1986) The development of platinumgroup minerals in laterites. Economic Geology, 81, 1278-1285.

Bowles, J.F.W. (1988) Further studies of the development of platinum-group minerals in the laterites of the Freetown Layered Complex, Sierra Leone. Pp. 273-280 in: Proceedings of the Symposium GeoPlatinum 87. (H.M. Prichard, P.J. Potts, J.F.W. Bowles and S.J. Cribb, editors). Elsevier Applied Science, London.

Bowles, J.F.W. (1995) The development of platinum-group minerals (PGM) in laterites: mineral morphology. Chronique de la Recherche Minière, 520, 55-63.

Bowles, J.F.W. (2000a) Prassoite, vysotskite and keithconnite from the Freetown Layered Complex, Sierra Leone. Mineralogy and Petrology, 68, 75-84.

Bowles, J.F.W. (2000b) A primary platinum occurrence in the Freetown Layered Intrusion, Sierra Leone. Mineralium Deposita, 35, 583-586.

Bowles, J.F.W., Atkin, D., Lambert, J.L.M., Deans, T. and Phillips, R. (1983) The chemistry, reflectance and cellsize of the erlichmanite $\left(\mathrm{OsS}_{2}\right)$-laurite $\left(\mathrm{RuS}_{2}\right)$ series. Mineralogical Magazine, 47, 465-471.

Bowles, J.F.W., Giże, A.P. and Cowden, A. (1994a) The mobility of the platinum-group elements in the soils of the Freetown Peninsula, Sierra Leone. The Canadian Mineralogist, 32, 957-967.

Bowles, J.F.W., Giże, A.P., Vaughan, D.J. and Norris, S.J., (1994b) The development of platinum-group minerals in laterites; an initial comparison of the organic and inorganic controls. Transactions of the Institute of 


\section{J. F. W. BOWLES ETAL.}

Mining and Metallurgy, (Section B, Applied Earth Science), 103, B53-B565.

Bowles, J.F.W., Giże, A.P., Vaughan, D.J. and Norris, S.J. (1995) Organic controls on platinum-group element (PGE) solubility in soils: initial data. Chronique de la Recherche Minière, 520, 65-73.

Bowles, J.F.W., Lyon, I.C., Saxton, J.M. and Vaughan, D. J. (2000) The origin of platinum group minerals from the Freetown Intrusion, Sierra Leone, inferred from osmium isotope systematics. Economic Geology, 95, 539-548.

Bowles, J.F.W., Prichard, H.M., Suárez, S. and Fisher, P.C. (2013) The first report of platinum-group minerals in magnetite-bearing gabbro, Freetown Layered Complex, Sierra Leone: occurrences and genesis. The Canadian Mineralogist, 51, 455-473.

Bowles, J.F.W., Suárez, S., Prichard, H.M. and Fisher, P.C. (2017) Weathering of PGE-sulfides and Pt-Fe alloys, in the Freetown Layered Complex, Sierra Leone. Mineralium Deposita, Published on-line 20 January 2017, https://doi.org/10.1007/s00126-016-0706-4

Burgath, K.-P. (1988) Platinum-group minerals in ophiolitic chromitites and alluvial placer deposits, MetatusBobaris Area, Southeast Kalimantan. Pp. 343-403 in: Proceedings of the Symposium Geo-Platinum 87. (H.M. Prichard, P.J. Potts, J.F.W. Bowles and S.J. Cribb, editors). Elsevier Applied Science, London.

Cabral, A.R., Beaudoin, G., Choquette, M., Lehmann, B. and Polônia, J.C. (2007) Supergene leaching and formation of platinum in alluvium: evidence from Serro, Minas Gerais, Brazil. Mineralogy and Petrology, 90, 141-150.

Cabral, A.R., Galbiatti, H.F., Kwitko-Ribeiro, R. and Lehmann, B. (2008) Platinum enrichment at low temperatures and related microstructures, with examples of hongshiite $(\mathrm{PtCu})$ and empirical ' $\mathrm{Pt}_{2} \mathrm{HgSe}_{3}$ ' from Itabira, Minas Gerais, Brazil. Terra Nova, 20, 32-37.

Cabri, L.J. (editor) (1981) Platinum-Group Elements: Mineralogy, Geology, Recovery. The Canadian Institute of Mining and Metallurgy, Special Volume, 23, $267 \mathrm{pp}$.

Cabri, L.J. and Genkin, A.D. (1991) Re-examination of Pt alloys from lode and placer deposits, Urals. The Canadian Mineralogist, 29, 419-425.

Cabri, L.J. and Harris, D.C. (1975) Zoning in Os-Ir alloys and the relation of the geological and tectonic environment of the source rocks to the bulk Pt:Pt+Ir + Os ratio for placers. The Canadian Mineralogist, 13, 266-274.

Cabri, L.J. and Laflamme, J.H.G. (1997) Platinum-group minerals from the Konder Massif, Russian Far East. The Mineralogical Record, 28, 97-106.

Cabri, L.J., Criddle, A.J., Laflamme, J.H.G., Bearne, G.S. and Harris, D.C. (1981) Mineralogical study of complex Pt-Fe nuggets from Ethiopia. Bulletin de Minéralogie, 104, 508-525.
Cabri, J.L., Harris, D.C. and Weiser, T.W. (1996) Mineralogy and distribution of platinum-group mineral (PGM) placer deposits of the world. Exploration and Mining Geology, 5, 73-167.

Cassedanne, J.P. and Alves, J.N. (1992) Palladium and platinum from Córrego Bom Sucesso, Minas Gerais, Brazil. The Mineralogical Record, 23, 471-474.

Cousins, C.A. (1973) Platinoids in the Witwatersrand system. Journal of the South African Institute of Mining Metallurgy, 73, 184-199.

Cousins, C.A. and Kinloch, E.D. (1976) Some observations on textures and inclusions in alluvial platinoids. Economic Geology, 71, 1377-1398.

Duparc, L. and Tikonowitch, M.-N. (1920) Le platine et les gítes platinifères de l'Oural et du monde. Genéve Société anonyme de éditions Sonor, 542 pp.

Evstigneeva, T.L. (2009) Phases in the Pt-Fe system. Vestnik Otdelenia nauk o Zemle RAN, 1, 1-2.

Forde, W. (2011) The Story of Mining in Sierra Leone. Xlibris LLC, Dartford, UK, pp. 78.

Fuchs, W.A. and Rose, A.W. (1974) The geochemical behavior of platinum and palladium in the weathering cycle in the Stillwater Complex, Montana. Economic Geology, 69, 332-346.

Gregory, S. (1962) The raised beaches of the Peninsular area of Sierra Leone. Transactions and Papers, Institute of British Geographers, Publication No 31, 15-22.

Hagen, D, Weiser, T.H. and Than, H. (1990) Platinumgroup minerals in Quaternary gold placers in the upper Chindwin area of Northern Burma. Mineralogy and Petrology, 42, 265-286.

Harris, D.C. and Cabri, L.J. (1991) Nomenclature of platinum-group-element alloys: review and revision. The Canadian Mineralogist, 29, 231-237.

Hattori, K.H., Cabri, L.J. and Hart, S.R. (1991) Osmium isotope ratios of PGM grains associated with the Freetown Layered Complex, Sierra Leone, and their origin. Contributions to Mineralogy and Petrology, 109, 10-18.

Hattori, K.H., Chalokwu, C.I. and Hart, S.R. (1996) Fluid introduction of ${ }^{187} \mathrm{Os}$ into a solidified magma chamber: Evidence from the Freetown Layered Complex, Sierra Leone. EOS, Transactions of the American Geophysical Union, 77, S-277.

Hattori, K.H., Takahashi, Y. and Augé, T. (2010) Mineralogy and origin of oxygen-bearing platinumiron grains based on an X-ray absorption spectroscopy study. American Mineralogist, 95, 622-630.

Hughes, R.H. and Hughes, J.S. (1992) A Directory of African Wetlands. IUCN, Gland, Switzerland and Cambridge, UK/UNEP, Nairobi, Kenya/WCMC, Cambridge, UK, 820 pp.

Hussak, E. (1906) O palladio e a platina do Brasil. Annaes Escola de Minas de Ouro Preto, 8, 75-188.

Johan, Z., Ohnenstetter, M., Fischer, M. and Amossé, J. (1990) Platinum-group minerals from the Durance 
river alluvium, France. Mineralogy and Petrology, 42, 287-306.

Junner, N.R. (1929) Report of the Geological Department for part of the year 1927 and for the year 1928. Government printer, Freetown, $17 \mathrm{pp}$.

Junner, N.R. (1930) Geology and mineral resources of Sierra Leone. Mineralogical Magazine, 42, 73-82.

Kwitko, R., Cabral, A.R., Lehmann, B., Laflamme, J.H. G., Cabri, L.J., Criddle, A.J. and Galbiatti, H.F. (2002) Hongshiite, $\mathrm{PtCu}$, from Itabirite-hosted $\mathrm{Au}-\mathrm{Pd}-\mathrm{Pt}$ mineralization (Jacutinga), Itabira District, Minas Gerais, Brazil. The Canadian Mineralogist, 40, 711-723.

Locmelis, M., Melcher, F. and Oberthür, T. (2010) Platinum-group element distribution in the oxidized Main Sulfide Zone, Great Dyke, Zimbabwe. Mineralium Deposita, 45, 93-109.

Malitch, K.N. and Thalhammer, O.A.R. (2002) Pt-Fe nuggets derived from clinopyroxenite-dunite massifs, Russia: A structural, compositional and osmiumisotope study. The Canadian Mineralogist, 40, 395-418.

Mardock, C.L. and Barker, J.C. (1991) Theories on the transport and deposition of gold and PGM minerals in offshore placers near Goodnews Bay, Alaska. Ore Geology Reviews, 6, 211-227.

Melcher, F., Oberthür, T. and Lodziak, J. (2005) Modifications of detrital platinum-group minerals from the Eastern Bushveld Complex, South Africa. The Canadian Mineralogist, 43, 1711-1734.

Ndjigui, P.-D. and Bilong, P. (2010) Platinum-group elements in the serpentinite lateritic mantles of the Kongo-Nkamouna ultramafic massif (Lomié region, South-East Cameroon). Journal of Geochemical Exploration, 107, 63-76.

Nixon, G.T., Cabri, J.L. and Laflamme, J.H.G. (1990) Platinum-group-element mineralization in lode and placer deposits associated with the Tulameen Alaskantype complex, British Columbia. The Canadian Mineralogist, 28, 503-535.

Oberthür, T. and Melcher, F. (2005) Behaviour of PGE and PGM in the supergene environment: a case study of persistence and redistribution in the Main Sulfide Zone of the Great Dyke, Zimbabwe. Pp. 97-111 in: Exploration for Platinum-Group Element Deposits (J. E. Mungall, editor). Mineralogical Association of Canada, Short Course 5 35. Mineralogical Association of Canada, Quebec, Canada.

Oberthür, T., Weiser, T.W., Gast, L., Schoenberg, R. and Davis, D.W. (2002) Platinum-group minerals and other detrital components in the Karoo-age Somabula gravels, Gweru, Zimbabwe. The Canadian Mineralogist, 40, 435-456.

Oberthür, T., Weiser, T.W. and Gast, L. (2003) Geochemistry and mineralogy of platinum-group elements at Hartley Platinum Mine Zimbabwe.
Part 2: Supergene redistribution in the oxidized Main Sulfide Zone of the Great Dyke, and alluvial platinumgroup minerals. Mineralium Deposita, 38, 344-355.

Oberthür, T., Weiser, T.W., Melcher, F., Gast, L. and Wöhrl, C. (2013) Detrital platinum-group minerals in rivers draining the Great Dyke, Zimbabwe. The Canadian Mineralogist, 51, 197-222.

Ottemann, J. and Augustithis, S.S. (1967) Geochemistry and origin of "platinum-nuggets" in lateritic covers from ultrabasic rocks and birbirites of W. Ethiopia. Mineralium Deposita, 1, 269-277.

Pawlak, J., Łodyga-Chruścińska, E. and Chrustowicz, J. (2014) Fate of platinum metals in the environment. Journal of Trace Elements in Medicine and Biology, 28, 247-254.

Pollett, J.D. (1931) Platinum mining in Sierra Leone. Engineering and Mining World, 2, 747-748.

Pollett, J.D. (1951) The geology and mineral resources of Sierra Leone. Colonial Geology and Mineral Resources, 2, 3-28.

Prichard, H.M. and Fisher, P.C. (2012) Identification of platinum and palladium particles emitted from vehicles and dispersed into the surface environment. Environmental Science and Technology, 46, 3149-3154.

Prichard, H.M., Ixer, R.A., Lord, R.A., Maynard, J. and Williams, N. (1994) Assemblages of platinum-group minerals and sulfides in silicate lithologies and chromite-rich rocks within the Shetland ophiolite. The Canadian Mineralogist, 32, 271-294.

Prichard, H.M., Jackson, M. and Sampson, J. (2009) Dispersal and accumulation of $\mathrm{Pt}, \mathrm{Pd}$ and $\mathrm{Rh}$ derived from a roundabout in Sheffield (UK): from stream to tidal estuary. Science of the Total Environment, 401, 90-99.

Reith, F., Zammit, C.M., Shar, S.S., Etschmann, B., Bottrill, R., Southam, G., Ta, C., Kilburn, M., Oberthür, T., Bail, A.S. and Brugger, J. (2016) Biological role in the transformation of platinum-group mineral grains. Nature Geoscience, 9, 294-298, Published on-line 21 March 2016, https://doi.org 10.1038/NGEO2679

Salinas, R., Muñoz, R., Burgath, K.-P. and Tistl, M. (1992) Mineralizaciones primarias de elementos del grupo del platino en el complejo ultramáfico zonado del Alto Condoto, Chocó, Colombia. Internal Report 10927. INGEOMINAS-BGR, Medellín, 216 pp.

Suárez, S., Prichard, H.M., Velasco, F., Fisher, P.C. and McDonald, I. (2010) Alteration of platinum-group minerals and dispersion of platinum-group elements during progressive weathering of the Aguablanca Ni-Cu deposit, SW Spain. Mineralium Deposita, 45, 331-350.

Talovina, I.V. and Lazarenkov, V.G. (2001) Distribution and genesis of platinum group minerals in nickel ores of the Sakhara and Elizavet deposits in the Urals. Lithology and Mineral Resources, 36, 116-122. 


\section{J. F. W. BOWLES ETAL.}

Tistl, M (1994). Geochemistry of platinum-group elements of the zoned ultramafic Alto Condoto complex, northwest Colombia. Economic Geology, 89, $158-167$.

Wang, C.Y., Prichard, H.M., Zhou, M.-F. and Fisher, P.C. (2008) Platinum-group minerals from the Jinbaoshan Pt-Pd-deposit, SW China: evidence for magmatic origin and hydrothermal alteration. Mineralium Deposita, 43, 791-803.

Weiser, T.W. (2002) Platinum-group minerals (PGM) in placer deposits. Pp. 721-756 in: The Geology, Geochemistry, Mineralogy, and Mineral Beneficiation of Platinum-Group Elements. (L.J. Cabri, editor). Canadian Institute of Mining, Metallurgy and Petroleum, Special Volume 54.

Weiser, T.W. and Bachmann H.G. (1999) Platinum-group minerals from the Aikora River area, Papua
New Guinea. The Canadian Mineralogist, 37, 1131-1145.

Zaccarini, F., Pushkarev, E., Garuti, G., Krause, J., Dvornik, G.P., Stanley, C. and Bindi, L. (2013) Platinum group minerals (PGM) nuggets from alluvial-eluvial placer deposits in the Uktus concentrically zoned maficultramafic complex (Central Urals, Russia). European Journal of Mineralogy, 25, 519-531.

Zaitsev, V.P., Loginov, V.A., Melkomukov, V.N., Vorogushin, N.T., Vildanova, E.Y., Litvinov, A.F., Patoka, M.G. and Sidorov, E.G. (1998) The new biggest platinum province of NW Pacific. Abstract, 8th International Platinum Symposium, pp. 461-463.

Zhernovsky, I.V., Mochalov, A.G. and Rudashevsky, N.S. (1985) Phase inhomogeneity of isoferroplatinum enriched in iron. Doklady Akademii Nauk SSSR, 283, 196-200. 